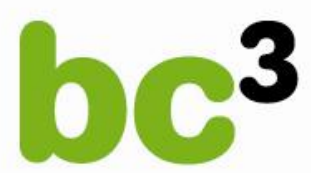

BASQUE CENTRE

FOR CLIMATE CHANGE

Klima Aldaketa Ikergai

\title{
The Determinants of Energy Efficiency Investments in the U.S.
}

Luis Mari Abadie, Ramon Arigoni Ortiz and Ibon Galarraga

October 2010

BC3 WORKING PAPER SERIES 
The Basque Centre for Climate Change (BC3) is a Research Centre based in the Basque Country, which aims at contributing to long-term research on the causes and consequences of Climate Change in order to foster the creation of knowledge in this multidisciplinary science.

The BC3 promotes a highly-qualified team of researchers with the primary objective of achieving excellence in research, training and dissemination. The Scientific Plan of BC3 is led by the Scientific Director, Prof. Anil Markandya.

The core research avenues are:

- Adaptation to and the impacts of climate change

- Measures to mitigate the amount of climate change experienced

- International Dimensions of Climate Policy

- Developing and supporting research that informs climate policy in the Basque Country

See www.bc3research.org for further details.

The BC3 Working Paper Series is available on the internet at http://www.bc3research.org/lits_publications.html

Enquiries (Regarding the BC3 Working Paper Series):

Roger Fouquet

Email: roger.fouquet@bc3research.org

www.bc3research.org

The opinions expressed in this working paper do not necessarily reflect the position of Basque Centre for Climate Change (BC3) as a whole.

Note: If printed, please remember to print on both sides. Also, perhaps try two pages on one side. 


\title{
The Determinants of Energy Efficiency Investments in the U.S.
}

\author{
Luis Mari Abadie ${ }^{1}$, Ramon Arigoni Ortiz ${ }^{1}$ and Ibon Galarraga ${ }^{1}$
}

This paper analyses decisions on energy efficiency (EE) investments by small and medium manufacturing enterprises in the U.S. which have received assessment from the Department of Energy (DoE). The results confirm the importance of payback time and investment costs as the main determining factors in deciding whether to invest in energy efficiency. This behaviour is kept through time. Such investment recommendations are frequently not implemented even though they apparently entail major advantages and give rise to considerable energy savings. The data show results which are compatible with a series of elementary valuation processes (limited by the availability of information), far removed from other, more academically ambitious methods such as Net Present Value (NPV) and the Real Options (RO) method. The paper analyses the impact of the physical situation of firms in line with their geographical locations in different US states, and changes over time from 1984 to 2008, i.e. 25 years of information. Finally, the paper examines the different levels of effectiveness of participating centres in getting firms to decide to make the investments proposed. EE investment decisions are analysed here using Logit models whose parameters are calibrated on the basis of the information held in the Industrial Assessment Centres (IAC) database. The results shed some light on impact assessment and suggest various policies for promoting investment in EE.

Keywords: Energy efficiency, energy assessments, energy policies

JEL Classification: Q40, N72, C51, C22

Cite as: Abadie, L.M.; R.A. Ortiz and I. Galarraga (2010) The Determinants of Energy Efficiency investments in the U.S. BC3 Working Paper Series 2010-17. Basque Centre for Climate Change (BC3). Bilbao, Spain.

\footnotetext{
${ }^{1}$ Basque Centre for Climate Change (BC3). Alameda Urquijo, 4 - 4, 48008 Bilbao, Spain. Corresponding author E-mail: 1m.abadie@bc3research.org.
} 


\section{Introduction}

Energy transformation and consumption account for a large proportion of anthropogenic greenhouse gas (GHG) emissions. This means that energy efficiency policies form an essential part of climate policy and are a smart way of reducing the depletion of already scarce, limited natural resources. Indeed, energy efficiency (EE) has been one of the mainstays of energy policy in recent years, be it for reasons of competitiveness in the economy, availability of resources or other reasons of a more strategic, geopolitical nature.

For example, in regard to climate policy, the International Energy Agency (IEA) estimates that EE policies could bring about reductions of as much as 10-15\% in annual $\mathrm{CO} 2$ emissions worldwide at no additional cost (IEA, 2009)). Energy efficiency may also enable highly significant cost reductions to be made in most public and private activities, but the truth is that many private investments which are more than justified in economic terms are simply not made. This is known as the "energy efficiency paradox" (Jaffe et al 2004, Linares and Labandeira 2010), and can be explained by barriers such as insufficient information, the "principal-agent" problem, difficulties in gaining access to capital and even divergence between private and social discount rates.

In the USA, as in many other countries, efforts in this area have formed a core part of energy policy. In this context one of the longest-running policies is the so-called programme of "Industrial Assessment Centres (IAC)" of the U.S. Department of Energy's Office of Energy Efficiency and renewable Energy ${ }^{2}$. This programme has been in place since 1976, with the main aim of getting industry to increase productivity and reduce its environmental impact through energy efficiency, waste minimisation and the prevention of atmospheric pollution.

The programme works basically through in-plant assessment, i.e. energy audits or evaluations are performed on site at Small and Medium Enterprises (SME) in the manufacturing sector. To have access to the programme, applicants must meet the following requirements ${ }^{3}$ :

- Gross sales of at least US\$100 million per annum.

- Energy costs of between $\$ 100,000$ and $\$ 2.5$ million per year.

- No more than 500 employees.

- No in-house technical specialists capable of performing investment analysis.

- A location no more than 150 miles from the campus of the participating centre that performs the assessment.

In-plant assessments are undertaken by staff and students from 26 centres at 31 renowned participating universities in the US. There has been some variation in the participating centres over

\footnotetext{
${ }^{2}$ For more information see http://www.iac.rutgers.edu

${ }^{3}$ Requirements defined for those SMEs with standard industrial classification (SIC) codes 20 to 39.
} 
the years, as can be seen in the IAC database. To date ${ }^{4}$, more than 14,000 assessments have been performed and 108,000 recommendations made.

The IAC database, on which this paper is based, has sparked the interest of a limited number of researchers, as described briefly in the following section. Among the resulting papers, Anderson and Newell (2004) stands out: their main result is that, consistent with the aforesaid energy efficiency paradox, the firms analysed seem to be more sensitive to investment costs than to the savings that can be made as a result of energy efficiency measures.

\section{Earlier Studies}

The main studies that have made use of the information in the IAC database to date are Tonn and Martín (2000); Anderson and Newell (2004); Dobbs (2009); and Muthulingam et al (2009). Tonn and Martín (2000) analyse the changes over time in corporate decision-making on energy efficiency using a seven-stage model that covers eventualities from zero consideration of energy efficiency in decision-making to excellence in EE management in situations where it has become a fundamental part of the corporate culture. Their results show that the number of potential improvements in EE drops over time, due mainly to the fact that the best opportunities for improvement are taken up first, with more complex, less effective measures being left for subsequent years. This effect is present even when new improvements arise as a result of developments in technology.

According to these authors the main purpose of the IAC programme is three-fold: (1) to speed up the transition to higher stages of the life-cycle model through assessment; (2) to train students and personnel with a view to their being hired by the firms in question; and (3) to distribute information through the programme's website. The method used in the paper involves questionnaires sent to firms that have undergone IAC assessments, to students who have taken part in the programme and to users of the IAC website ${ }^{5}$. The main conclusion is that firms which have undergone IAC assessment advance, on average, one stage further in the life-cycle model in a few years.

The paper by Anderson and Newell (2004) cited above analyses decisions by manufacturing firms that use the IAC programme. They develop a number of Logit models that the authors calibrate with data from 1981-2000 ${ }^{6}$. Their results show positive impacts for the following variables: shorter payback periods, lower investment cost, greater annual energy savings, increased energy costs and greater energy conservation.

Muthulingam et al (2009) uses the IAC database to compare four hypotheses: (a) the shortsightedness of firms that fail to adopt certain EE measures in spite of their high rate of return; (b) the

\footnotetext{
${ }^{4} 04 / 15 / 2010$

5 The questionnaires were answered by 42 companies, 132 former students who had taken part in the assessments and 29 users of the IAC website.

${ }^{6}$ The payback model, the cost-benefit model and the price-quantity model.
} 
idea that firms give more importance to the cost of investment than to the potential savings; (c) the possible influence of the order in which assessment recommendations are made on their acceptance (with the first recommendations being the most likely to be accepted); and (d) the impact of the number of recommendations. Their results support the hypothesis that (a), (b) and (c) are all significant. In regard to (d), the acceptance ratio does not decrease when the number of recommendations per firm increases.

The papers by Anderson and Newell (2004) and Muthulingam et al (2009) highlight the importance of payback time as a particularly significant indicator for assessing whether investment in EE is implemented. Note that other, more technically appropriate indicators such as the Net Present Value (NPV) cannot be calculated with the information available: although the database contains a great deal of information it has nothing on the useful lifetime of investments or, therefore, on the total savings that may be obtained from them. If accurate information is not used, this point could be detrimental to the acceptance of investments with longer payback periods.

The short-term view, i.e. the implementation of investments that present shorter payback times, has a negative influence on decisions by firms, as it is conducive to low investment rates and a lack of innovation, features that both seem unsustainable over time. However, the evidence confirms that this behaviour does persist over time. The reason for this apparent paradox must be sought in financial variables such as uncertainty and liquidity constraints, under which it is optimal to stick to the shortest payback periods or the highest hurdle rates $^{7}$. For example increased uncertainty concerning income could justify some aspects of this behaviour in regard to costs.

The impact of short-termism is studied by Dobbs (2009) via a survey. His paper concludes that firms apply a high discount rate, sometimes more than $20 \%$, with required maximum payback times of just 2 or 3 years being relatively frequent. This simple rule of thumb is widespread among firms, and its application results in their ignoring specific features of investment projects, such as differences in risk.

Corporate decision-making models are studied by Graham and Harvey (2001), who report the results of a survey that elicited responses from 392 chief financial officers. This report shows that a large number of firms use company-wide discount rates to evaluate projects rather than projectspecific discount rates.

The present paper looks in greater depth at these issues by estimating various decisionmaking models that depend on different explanatory variables, but differs from earlier studies in that it does not assess the suitability of the actions taken by firms. The main objective is to help identify measures to support investment in EE that may be useful in decision-making and in public policy design, given that firms behave as reported in the IAC Database. The study refers solely to electricityrelated EE investments.

\footnotetext{
${ }^{7}$ The hurdle discount rate is the rate chosen by the company as the minimum yield required from new investments if they are to get the go-ahead.
} 


\section{The Data}

This paper uses the information contained in the IAC database at $04 / 15 / 2010$, i.e. 14,520 assessments with a total of 108,562 recommendations, which average out to 7.5 recommendations per assessment.

The information available has been adjusted for the purposes of this study as follows:

- Records dating from before 1984 and after 2008 are disregarded, so as to give a data period of 25 years with full information. The records for 2009 and 2010 were ruled out because the final outcomes of many of the recommendations are not yet known.

- The sample is restricted to decisions reported as "implemented" and "not implemented". This means excluding those recommendations whose status is not reported or is pending, and those recorded as "data excluded" or "unavailable".

- As a result of doubts concerning the quality of some data, recommendations with payback periods of more than 9 years and less than 0 are also excluded.

- A minor series of records concerned with Puerto Rico are excluded.

- Only those recommendations concerned with electricity are considered. This means that records containing information on secondary, tertiary and quaternary savings in a number of fuels are excluded. This is to prevent decisions from being tainted by prices other than electricity prices. However, secondary, tertiary and quaternary savings in resource costs and production are included.

After these detailed adjustments, the sample for analysis comprises 60,463 EE recommendations, listed according to different US states.

Preliminary analysis revealed that the IAC database lacked important information on a significant matter: the lifetime of each recommendation for improvement. Authors such as Muthulingam et al (2009) assume a lifetime of 3 years for projects of all types, while Anderson and Newell (2004) estimate that decisions by firms are compatible with the use of a hurdle rate of 50\%$100 \%$ for investments with useful lifetimes of 10 years or more.

\section{Preliminary Analysis}

The first point that emerges from an analysis of the 60,463 recommendations selected for this study is that the mean percentage of implementation is only $53.17 \%$. In other words, almost half the recommendations made do not ultimately result in a decision to invest. Bearing in mind the extremely high potential for improvement associated with investment in energy efficiency, as mentioned above, this percentage can be considered as relatively low. There may be various reasons for this finding. The present paper seeks to shed light on this issue, but before more technical points are considered it may be useful here to give some descriptive data to help readers appreciate the particular features of the results of the IAC programme. 
Figure 1

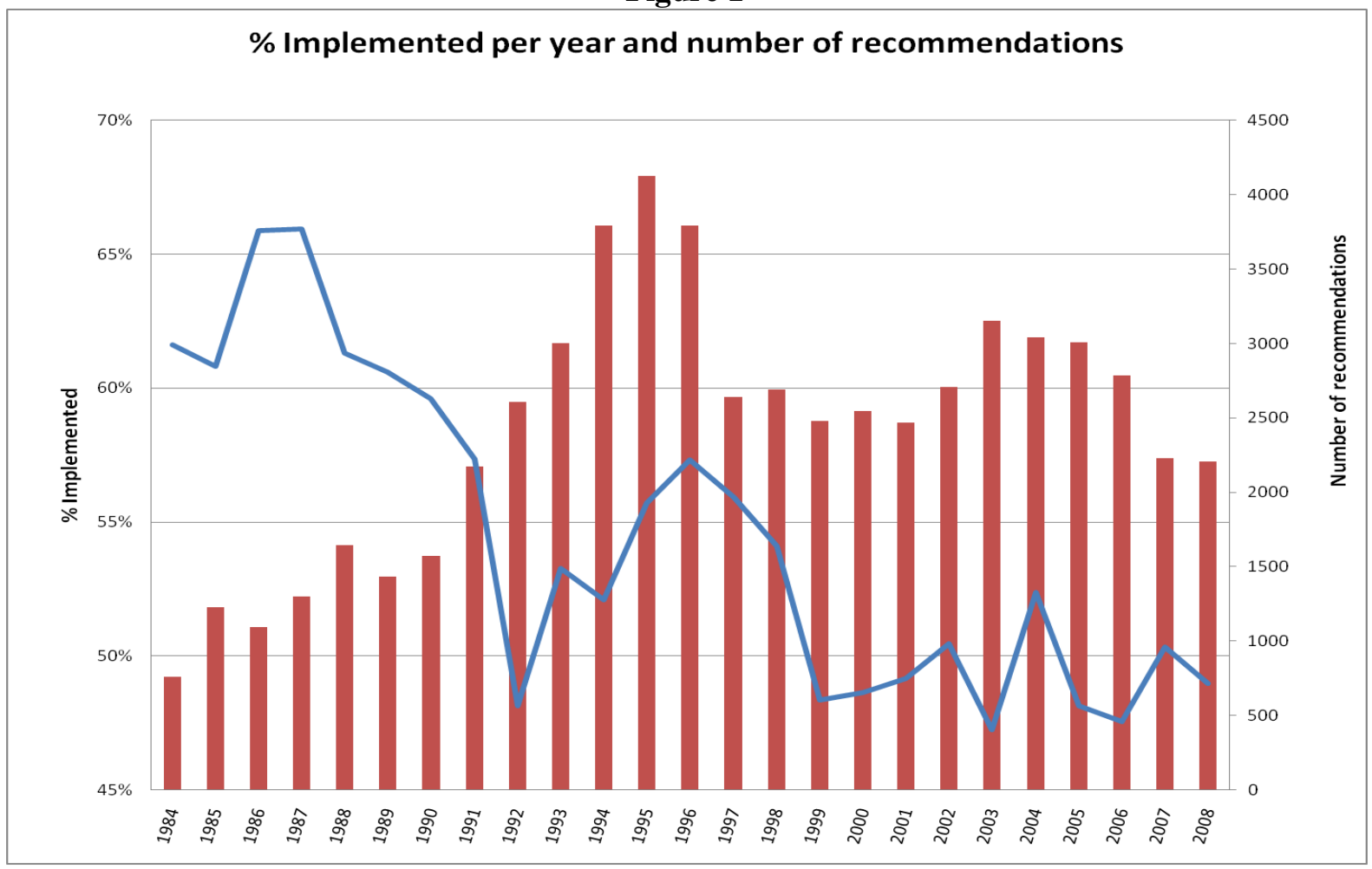

An analysis of the variations in the percentage of measures implemented over the whole time series (see Figure 1) reveals that it is higher between 1984 and 1989 and lowest between 2000 and 2008. At first sight the drop since 1995 and the trend over that time suggest a clear depletion effect in the best opportunities for investment, i.e. the easiest, most cost-effective measures are taken first and more complex actions are left for later. Unless there is a major depletion in improvement opportunities the results are not compatible with a shift to more sophisticated decision-making models. But if the degree of implementation industry by industry is considered (Figure 2) variations of between 47 and almost $57 \%$ can be seen in the implementation rate.

Implementation rates differ from one type of manufacturing industry (as per SIC code) to another, with the highest being found in Tobacco and Petroleum and Coal, and the lowest in Printing and Publishing. Even so, almost all manufacturing industries show acceptance rates of over 50\%.

There is great disparity from one industry to another in terms of the total number of recommendations made (see Figure 3), ranging from 29 for Tobacco to over 7,000 for Fabricated Metal Products, Rubber and Miscellaneous, and Food and Kindred. Given the different behaviour patterns of different groups, the significance of belonging to a particular industry is investigated below. 
Figure 2

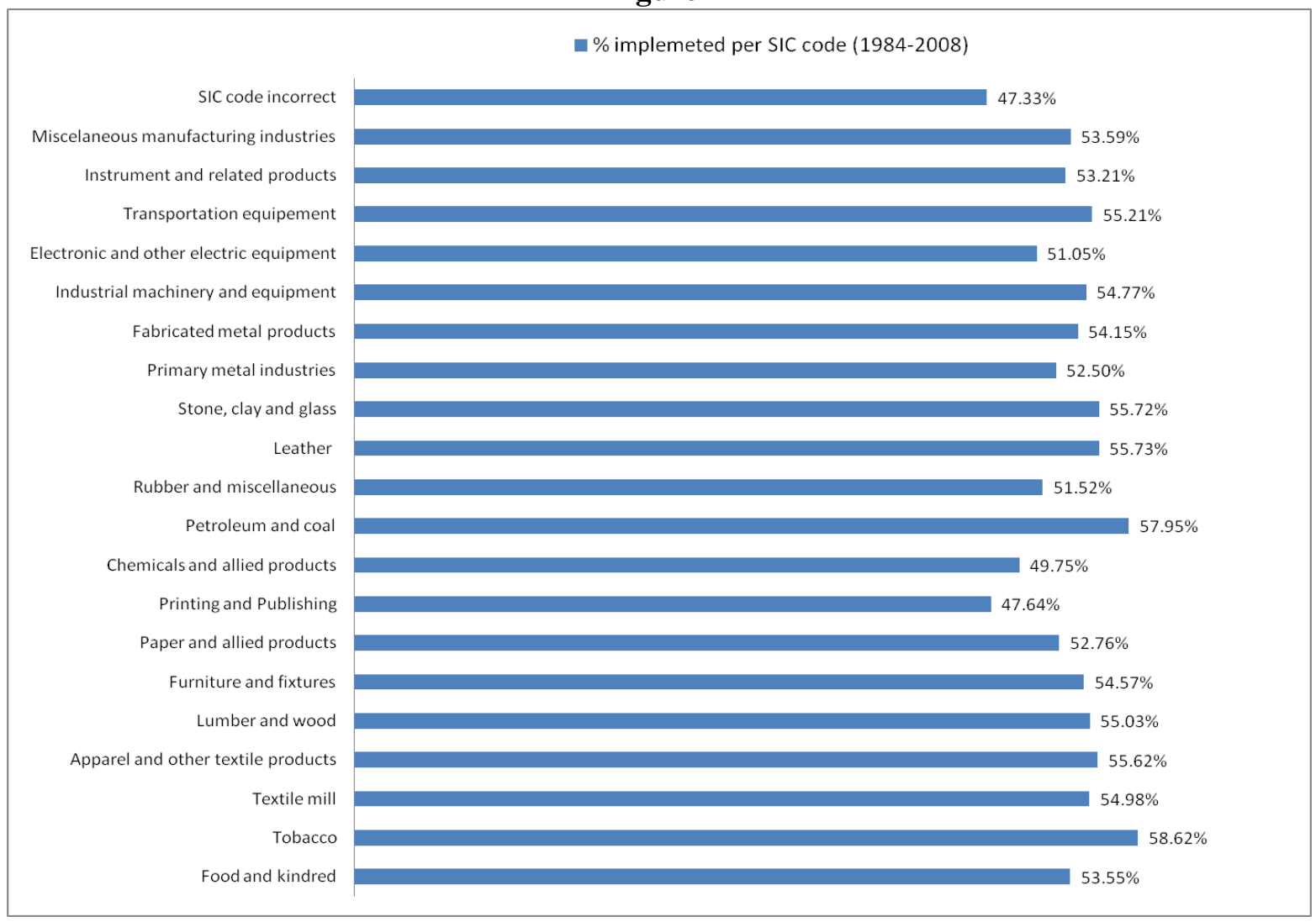

Figure 3

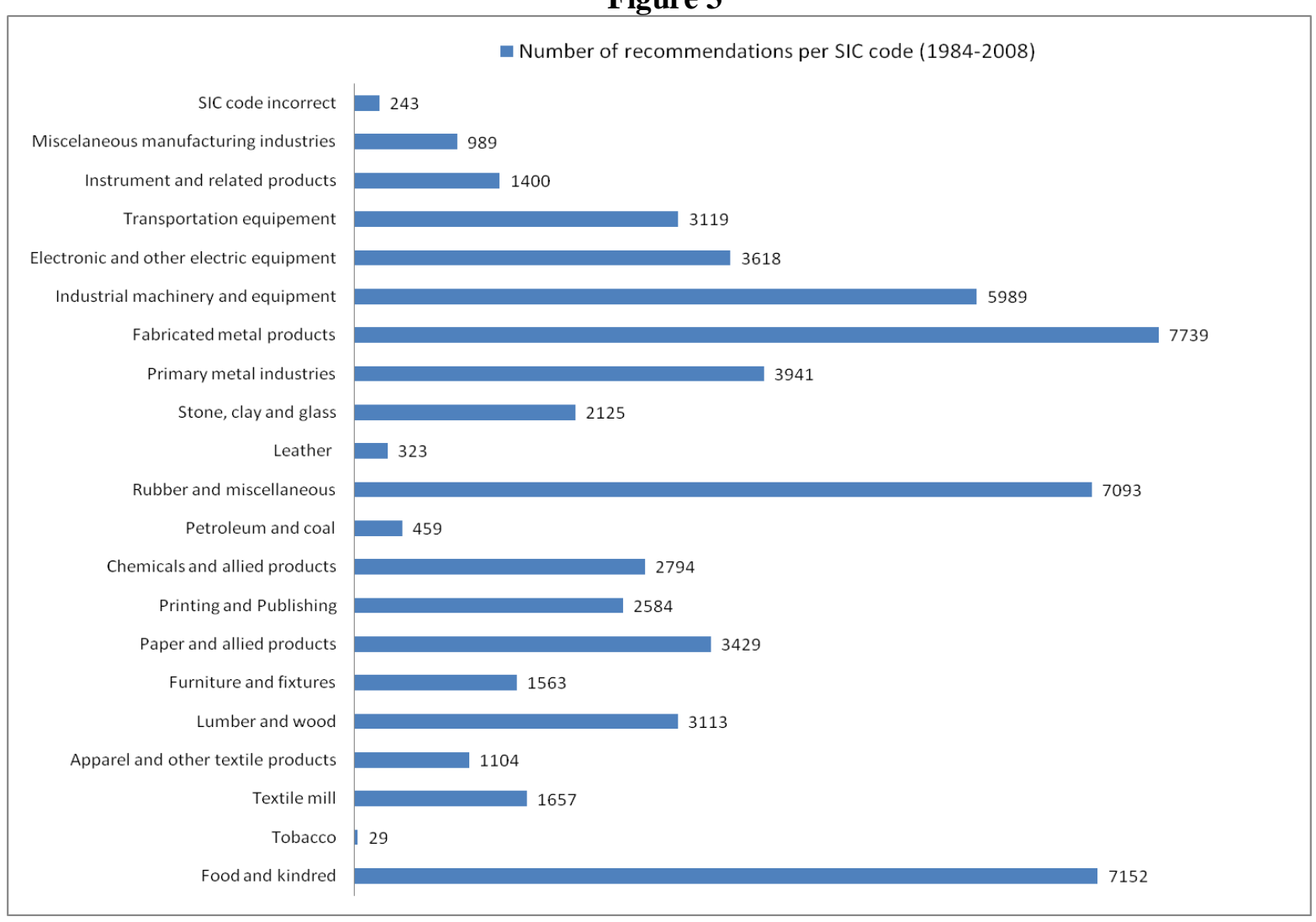


Figure 4 is consistent with the studies by Anderson and Newell (2004) and Muthulingam et al (2009) in showing payback time to be a determining factor in investment decisions for manufacturing SMEs in the USA. This assertion is checked below using econometric methods. It is not unreasonable to assume that this could result from a number of behavioural aspects such as shorttermism, budget constraints and incorrect investment assessment practices, among others. For instance, Graham et al (2005) show that 78\% of 400 CFO's in US public and private firms scarify long-term value in order to keep short term predictability in earnings. But it is important to point out that other financial aspects could be equally significant, such as the risk entailed by investments (e.g. technological risk), liquidity constraints and uncertainty affecting both income and costs. There seems to be no clear evidence that this behaviour has changed much over time, so the response of firms to these EE programmes is taken as given.

Figure 4

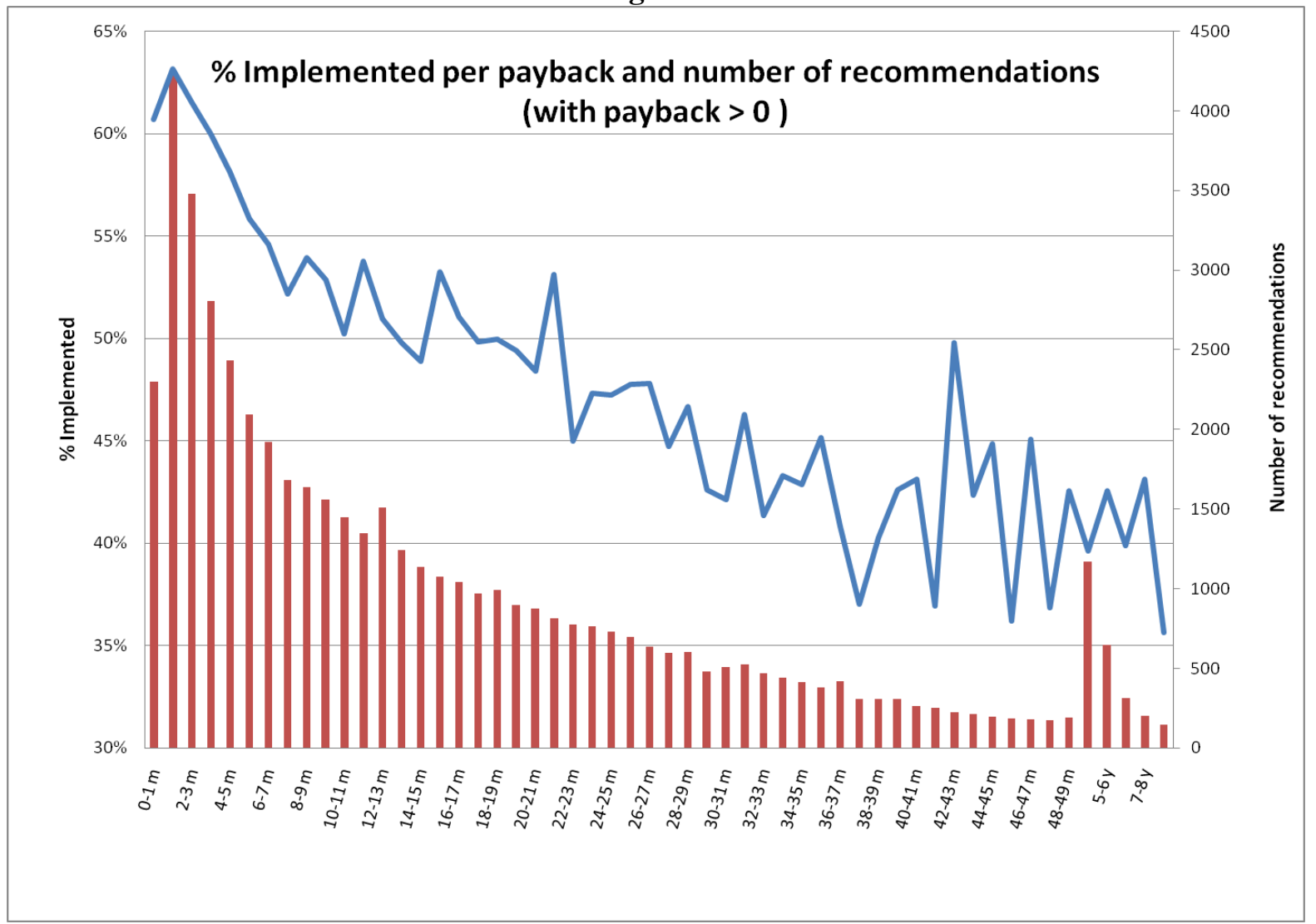

If the proportion of measures implemented is broken down by energy management $\mathrm{ARCs}^{8}$, the rate of acceptance of measures aimed at the Motor System stands out, in contrast to the very low rate for Total Energy Management measures (see Figure 5).

\footnotetext{
${ }^{8}$ ARC's are Assessment Recommendation Codes, in which recommendations are grouped by type (e.g. those concerned with air compressors) independently of the industrial classification of the firm where they are made.
} 
Figure 5

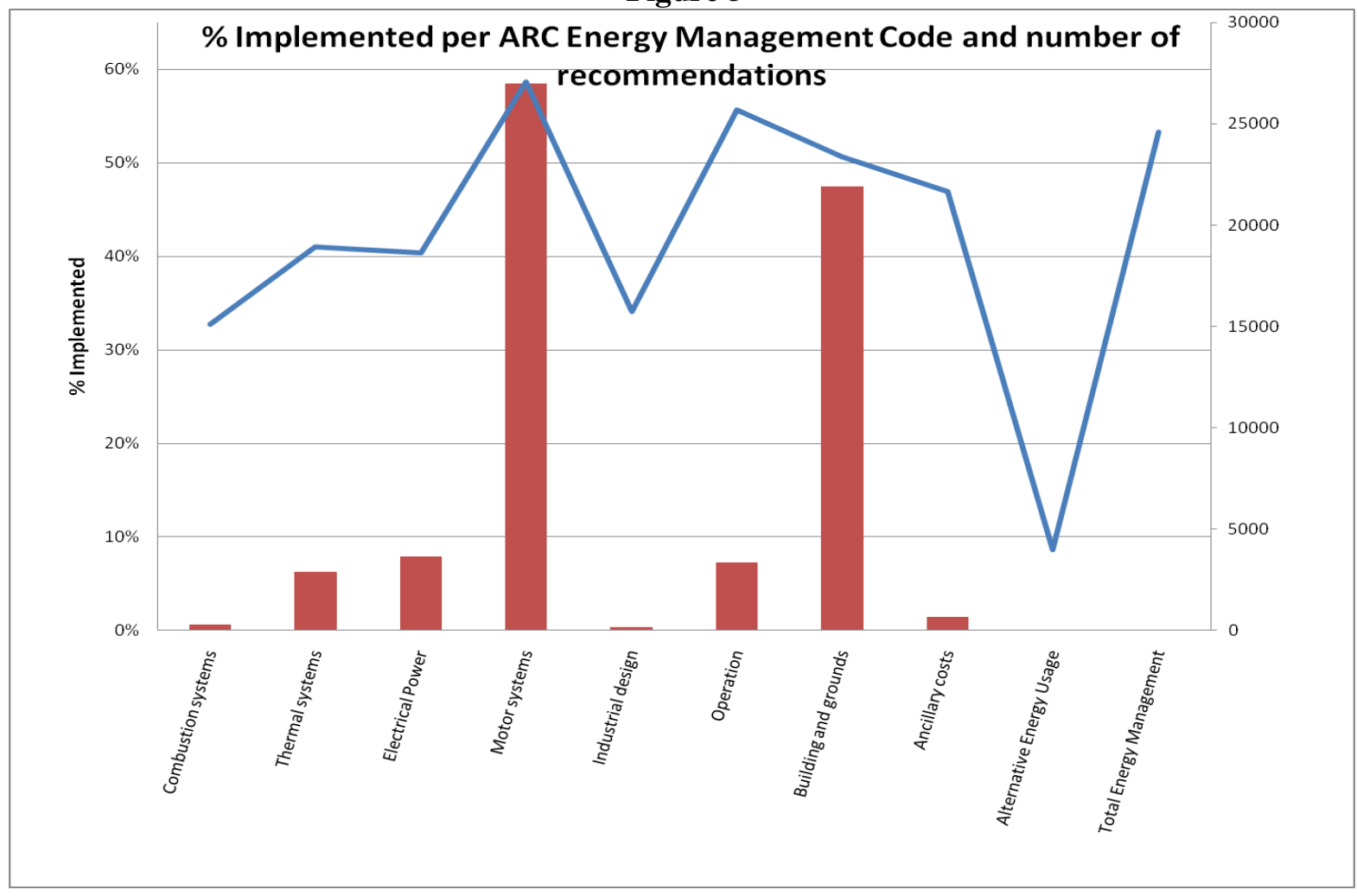

Investment cost is, of course, one of the measures that initially seem most relevant in decision-making concerning investment (Figure 6). As may be expected, the acceptance rate falls markedly as costs increase.

Figure 6

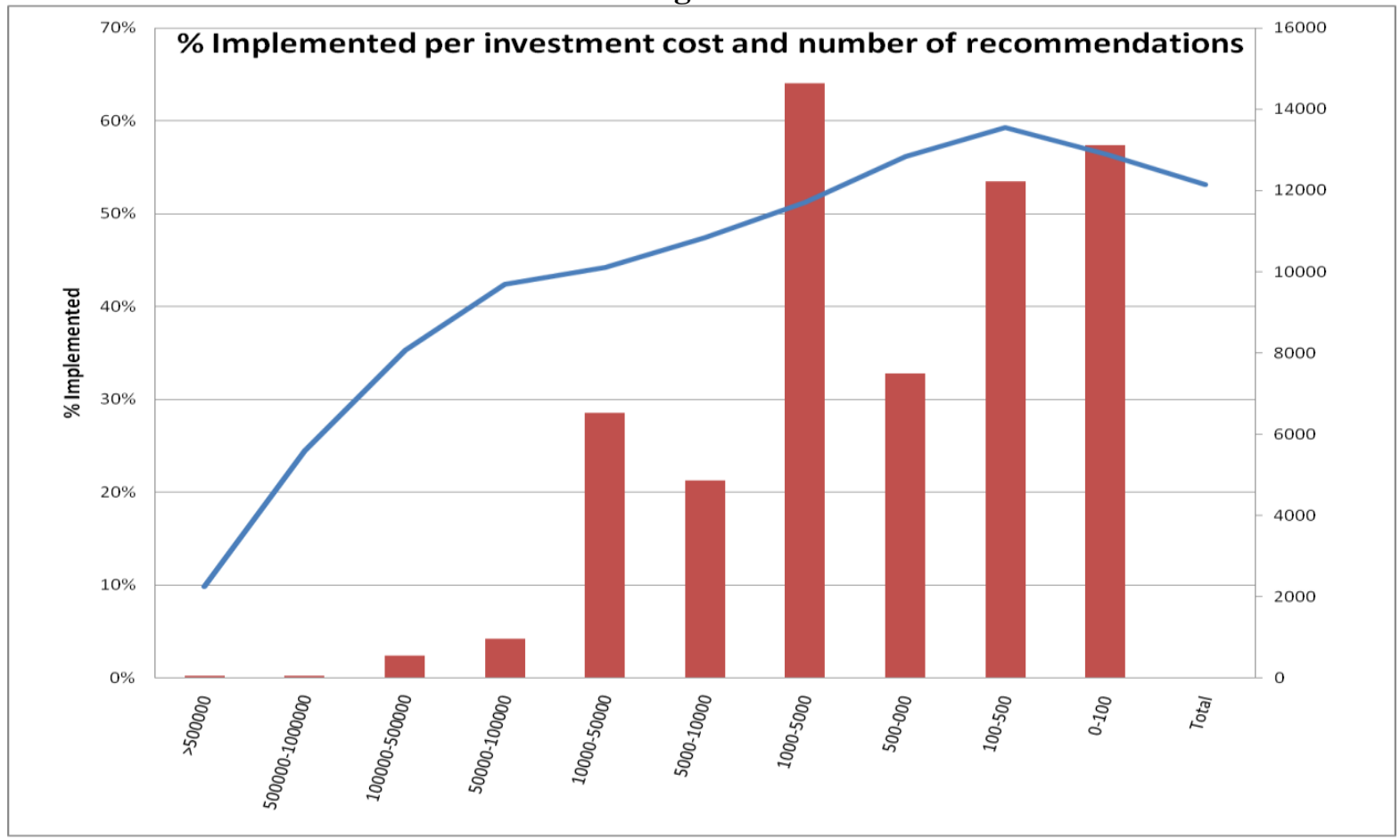


Another feature revealed by an analysis of the data is highlighted in Figure 7: for most firms the amount of sales (as an indicator of size) does not seem to have any clearly significant influence on the acceptance rate.

Figure 7

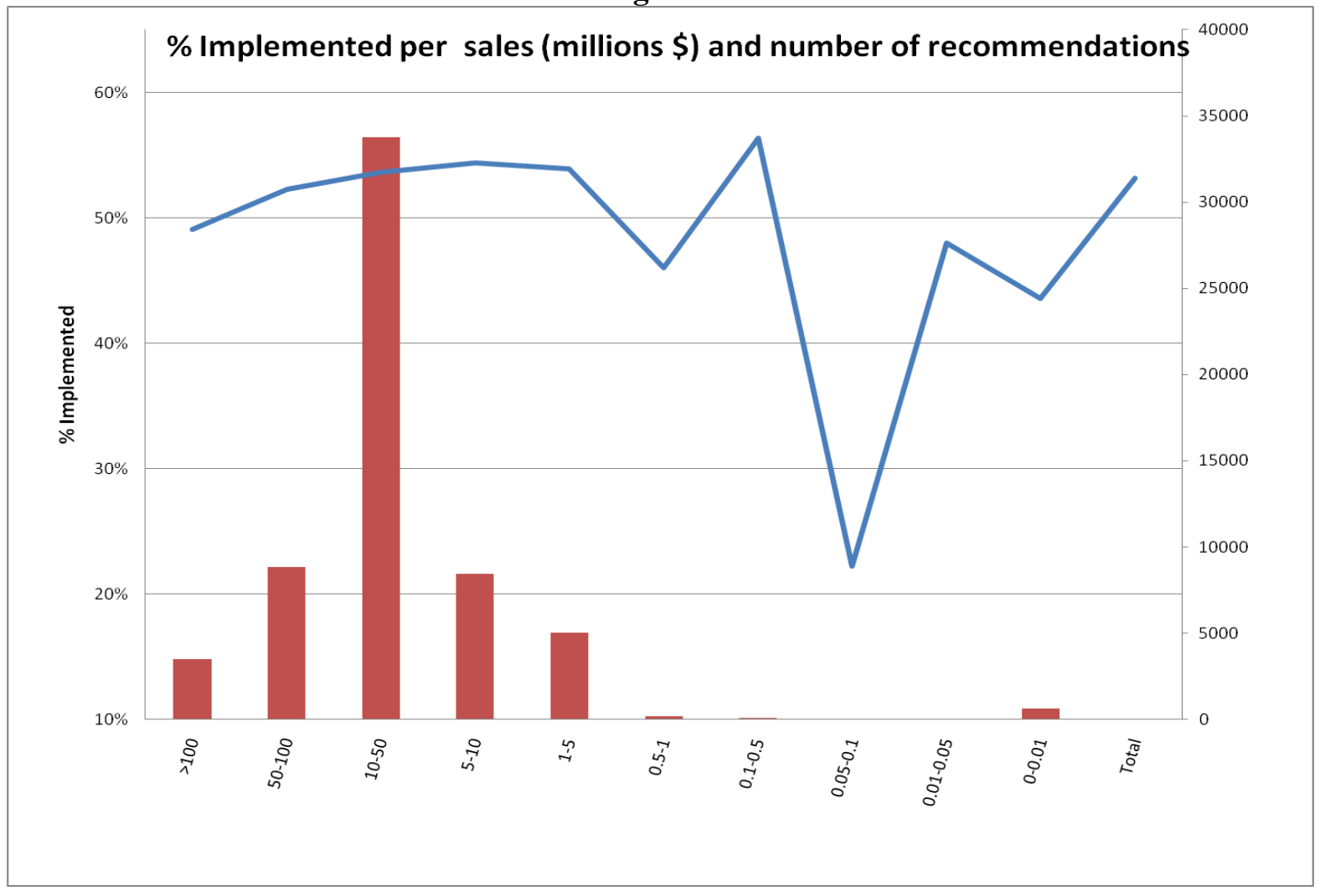

IAC data also reveal the distribution of the implementation rate of recommendations in terms of location by state. This information is shown in Table 1 below. The highest ranking state is Alaska with a $70 \%$ implementation rate, followed by West Virginia with $65 \%$, and the lowest is Utah with just $31 \%$. These data should be analysed together with other information such as the total number of recommendations and the number of companies per industry, but even so it raises many interesting questions. Is this difference explained by particular environmental and energy legislation in some States that it is not present in others? Or can it be put down to something related to the reputation of the centres making the recommendations? Answering to these questions is far beyond the scope of this paper but all of them are plausible explanations that should not be disdained. Table 2 offers some descriptive numbers regarding the IAC centres involved and the rate of implementation of their recommendations. 
Table 1

\begin{tabular}{|c|c|c|c|c|}
\hline State & Implemented & Not Implemented & Total & $\%$ Implemented \\
\hline Alaska & 26 & 11 & 37 & $70.27 \%$ \\
\hline Alabama & 290 & 274 & 564 & $51.42 \%$ \\
\hline Arkansas & 872 & 486 & 1358 & $64.21 \%$ \\
\hline Arizona & 1033 & 1372 & 2405 & $42.95 \%$ \\
\hline California & 2634 & 2439 & 5073 & $51.92 \%$ \\
\hline Colorado & 1394 & 866 & 2260 & $61.68 \%$ \\
\hline Connecticut & 268 & 256 & 524 & $51.15 \%$ \\
\hline Delaware & 83 & 108 & 191 & $43.46 \%$ \\
\hline Florida & 1360 & 1578 & 2938 & $46.29 \%$ \\
\hline Georgia & 1222 & 1049 & 2271 & $53.81 \%$ \\
\hline Hawaii & 33 & 19 & 52 & $63.46 \%$ \\
\hline Iowa & 937 & 758 & 1695 & $55.28 \%$ \\
\hline Idaho & 47 & 61 & 108 & $43.52 \%$ \\
\hline Illinois & 1489 & 1972 & 3461 & $43.02 \%$ \\
\hline Indiana & 676 & 845 & 1521 & $44.44 \%$ \\
\hline Kansas & 733 & 588 & 1321 & $55.49 \%$ \\
\hline Kentucky & 276 & 329 & 605 & $45.62 \%$ \\
\hline Louisiana & 649 & 561 & 1210 & $53.64 \%$ \\
\hline Massachusetts & 622 & 509 & 1131 & $55.00 \%$ \\
\hline Maryland & 140 & 135 & 275 & $50.91 \%$ \\
\hline Maine & 367 & 319 & 686 & $53.50 \%$ \\
\hline Michigan & 684 & 714 & 1398 & $48.93 \%$ \\
\hline Minnesota & 462 & 333 & 795 & $58.11 \%$ \\
\hline Missouri & 1475 & 965 & 2440 & $60.45 \%$ \\
\hline Mississippi & 507 & 716 & 1223 & $41.46 \%$ \\
\hline Montana & 18 & 14 & 32 & $56.25 \%$ \\
\hline North Carolina & 1206 & 913 & 2119 & $56.91 \%$ \\
\hline North Dakota & 17 & 28 & 45 & $37.78 \%$ \\
\hline Nebraska & 290 & 212 & 502 & $57.77 \%$ \\
\hline New Hampshire & 195 & 159 & 354 & $55.08 \%$ \\
\hline New Jersey & 575 & 554 & 1129 & $50.93 \%$ \\
\hline New Mexico & 60 & 71 & 131 & $45.80 \%$ \\
\hline Nevada & 249 & 263 & 512 & $48.63 \%$ \\
\hline New York & 842 & 693 & 1535 & $54.85 \%$ \\
\hline Ohio & 1628 & 1200 & 2828 & $57.57 \%$ \\
\hline Oklahoma & 1220 & 928 & 2148 & $56.80 \%$ \\
\hline Oregon & 904 & 668 & 1572 & $57.51 \%$ \\
\hline Pennsylvania & 975 & 795 & 1770 & $55.08 \%$ \\
\hline Rhode Island & 68 & 62 & 130 & $52.31 \%$ \\
\hline South Carolina & 195 & 182 & 377 & $51.72 \%$ \\
\hline South Dakota & 76 & 62 & 138 & $55.07 \%$ \\
\hline Tennessee & 839 & 705 & 1544 & $54.34 \%$ \\
\hline Texas & 2493 & 1599 & 4092 & $60.92 \%$ \\
\hline Utah & 128 & 281 & 409 & $31.30 \%$ \\
\hline Virginia & 543 & 472 & 1015 & $53.50 \%$ \\
\hline Vermont & 59 & 38 & 97 & $60.82 \%$ \\
\hline Washington & 317 & 259 & 576 & $55.03 \%$ \\
\hline Wisconsin & 527 & 651 & 1178 & $44.74 \%$ \\
\hline West Virginia & 400 & 212 & 612 & $65.36 \%$ \\
\hline Wyoming & 48 & 28 & 76 & $63.16 \%$ \\
\hline Total & 32151 & 28312 & 60463 & $53.17 \%$ \\
\hline
\end{tabular}


Table 2

\begin{tabular}{|l|r|r|r|r|}
\hline \multicolumn{5}{|c|}{ Active IAC Centres } \\
\hline \multicolumn{1}{|c|}{ Primary Centre } & Implemented & Not Implemented & Total & $\%$ Implemented \\
\hline Texas A\&M - College Station & 1780 & 1042 & 2822 & $63.08 \%$ \\
\hline Bradley University & 856 & 1007 & 1863 & $45.95 \%$ \\
\hline Colorado State University & 1585 & 1038 & 2623 & $60.43 \%$ \\
\hline Georgia Tech Research Institute & 1461 & 1185 & 2646 & $55.22 \%$ \\
\hline Iowa State University & 1307 & 1028 & 2335 & $55.97 \%$ \\
\hline University of Illinois - Chicago & 365 & 391 & 756 & $48.28 \%$ \\
\hline Lehigh University & 396 & 516 & 912 & $43.42 \%$ \\
\hline Louisiana University - Lafayette & 546 & 583 & 1129 & $48.36 \%$ \\
\hline University of Massachusetts & 1204 & 1045 & 2249 & $53.53 \%$ \\
\hline University of Miami & 279 & 399 & 678 & $41.15 \%$ \\
\hline Mississippi State University & 571 & 802 & 1373 & $41.59 \%$ \\
\hline University of Missouri - Columbia & 52 & 40 & 92 & $56.52 \%$ \\
\hline North Carolina State University & 832 & 747 & 1579 & $52.69 \%$ \\
\hline Oklahoma State University & 1461 & 1126 & 2587 & $56.47 \%$ \\
\hline Oregon State University & 1279 & 938 & 2217 & $57.69 \%$ \\
\hline San Diego State University & 1204 & 1011 & 2215 & $54.36 \%$ \\
\hline San Francisco State University & 1031 & 1114 & 2145 & $48.07 \%$ \\
\hline Syracuse University & 558 & 392 & 950 & $58.74 \%$ \\
\hline University of Tennessee & 1106 & 863 & 1969 & $56.17 \%$ \\
\hline Tennessee Tech & 52 & 106 & 158 & $32.91 \%$ \\
\hline University of Alabama & 68 & 95 & 163 & $41.72 \%$ \\
\hline University of Dayton & 1170 & 1044 & 2214 & $52.85 \%$ \\
\hline University of Florida & 1138 & 1238 & 2376 & $47.90 \%$ \\
\hline University of Michigan - Ann Arbor & 540 & 580 & 1120 & $48.21 \%$ \\
\hline University of Washington & 30 & 58 & 88 & $34.09 \%$ \\
\hline West Virginia University & 1599 & 819 & 2418 & $66.13 \%$ \\
\hline Total Active Centres & 22470 & 19207 & 41677 & $53.91 \%$ \\
\hline Former and Other Centres & 9681 & 9105 & 18786 & $51.53 \%$ \\
\hline Total Centres & 32151 & 28312 & 60463 & $53.17 \%$ \\
\hline
\end{tabular}

\section{Modelling and Estimation}

For the analysis presented here equation (1) has been drawn up to represent the choice of implementing or not implementing an EE improvement recommendation. If the recommendation is implemented it will result in a number of net benefits expressed by the latent variable $y^{*}$. It is the yes/ no decision of firms that is observable:

$$
y_{i j k l m m}^{*}=\psi\left(A_{i}, B_{j}, C_{k}, D_{l}, E_{m}, F_{n}\right)+\epsilon
$$

Where the sub-indices refer to:

(i) The characteristics of the EE investment project;

(j) The characteristics of the firm; 
(k) The state in which firms are located and those variables that may differ from one US state to another (e.g. environmental legislation, idiosyncratic features of employers, etc.);

(l) The influence of the SIC group to which firms belong;

(m) The impact of the type of investment as per its ARC;

(n) The influence of the IAC Centre that performs the assessment.

In this context the following can be observed:

$$
y_{i j k l m m}=1 \text { if } y_{i j k l m m}^{*}>0
$$

and

$$
y_{i j k l m m}=0 \text { if } y_{i j k l m m}^{*} \leq \mathbf{0}
$$

Therefore, we have the following for a Probit model:

$$
\operatorname{Pr}\left[y_{i j k l m m}=1\right]=\Phi\left(\psi\left(A_{i}, B_{j}, C_{k}, D_{l}, E_{m}, F_{n}\right)\right),
$$

Where $\varphi$ is the normal cumulative distribution function and $\psi$ has a normal distribution and is independent of $(\mathrm{A}, \mathrm{B}, \mathrm{C} \ldots)$.

\section{Data Description}

\begin{tabular}{|c|c|c|c|c|}
\hline Variable & Acronym & Obs. & Mean & Std. Dev. \\
\hline payback time & $\mathrm{PB}$ & 60,463 & 1.1082 & 1.3450 \\
\hline $\ln$ (payback time) & $\ln (\mathrm{PB})$ & 51,220 & -0.4119 & 1.4034 \\
\hline $\ln (\text { payback time })^{2}$ & $\ln (\mathrm{PB})^{2}$ & 51,220 & 2.1393 & 4.1873 \\
\hline State GDP & GDP & 60,464 & $45,145.28$ & 39684.13 \\
\hline $\ln ($ State GDP) & $\ln (\mathrm{GDP})$ & 60,463 & 10.3101 & 0.9725 \\
\hline $\ln (\text { State GDP })^{2}$ & $\ln (\mathrm{GDP})^{2}$ & 60,463 & 107,2435 & 19.6947 \\
\hline Emissions & EMI & 49,918 & 197,2448 & 159.7737 \\
\hline $\ln$ (Emissions) & $\ln (\mathrm{EMI})$ & 49,918 & 4,9738 & 0.8237 \\
\hline Year & YEAR & 60,463 & 1997.433 & 6.32228 \\
\hline $\operatorname{Ln}(\mathrm{EE}$ Cost $)$ & $\operatorname{Ln}($ Cost $)$ & 50,953 & 7.202315 & 1.919909 \\
\hline Ln(Yearly EE Benefits) & $\operatorname{Ln}(\mathrm{BEN})$ & 60,449 & 7.570395 & 1.504785 \\
\hline
\end{tabular}

The main details of the variables used in the estimation are shown in table 3:

Table 3:

Conventionally, models of this type result in around 11 variables, including both the log and the square (the latter to incorporate trend effects into the analysis). The mean payback time stands out among the data shown in table 3 . At 1.1082 this might be seen as a significantly small figure.

We used 7 different specifications in our estimations. They include a number of variations of the specifications of a model based on payback time (specifications 1,2,3) and a cost/benefit based model (specifications 4, 5, $6 \& 7$ ). These are the two families of model which are conventionally used in studies of this kind (e.g. Anderson and Newell (2004)). 
EE improvement policy to reduce the use of electricity is linked to reductions in emissions of $\mathrm{CO}_{2}, \mathrm{SO}_{2}$ and $\mathrm{NO}_{\mathrm{x}}$ pollutants. Taking the electricity generation mix into account, for each $1 \mathrm{MWh}$ saved in the US, averaged over the period 1997-2008, $629 \mathrm{~kg}$ of $\mathrm{CO}_{2}, 2.83 \mathrm{~kg}$ of $\mathrm{SO}_{2}$ and $1.26 \mathrm{~kg}$ of $\mathrm{NO}_{\mathrm{x}}$ have been saved. These data are shown in the following table 4, which also reveals the fall over time in pollution per MWh generated in the US.

Table 4

\begin{tabular}{|c|c|r|r|r|r|r|r|}
\hline \multicolumn{2}{|c|}{ US EMISSIONS } & \multicolumn{2}{|c|}{ Emissions (Thousand Metric Tons) } & \multicolumn{3}{c|}{ Emissions per MWh } \\
\hline Year & $\begin{array}{c}\text { Net Generation } \\
\text { Thousand } \\
\text { MWh) }\end{array}$ & $\begin{array}{c}\text { Carbon Dioxide } \\
\left(\mathrm{CO}_{2}\right)\end{array}$ & $\begin{array}{c}\text { Sulphur } \\
\text { Dioxide }\left(\mathrm{SO}_{2}\right)\end{array}$ & $\begin{array}{c}\text { Nitrogen } \\
\text { Oxides } \\
\left(\mathrm{NO}_{\mathrm{x}}\right)\end{array}$ & $\begin{array}{c}\text { Carbon } \\
\text { Dioxide } \\
\left(\mathrm{CO}_{2}\right) \mathrm{Kg}\end{array}$ & $\begin{array}{c}\text { Sulphur } \\
\text { Dioxide } \\
\left(\mathrm{SO}_{2}\right) \mathrm{Kg}^{\mathrm{K}}\end{array}$ & $\begin{array}{c}\text { Nitrogen } \\
\text { Oxides } \\
\left(\mathrm{NO}_{\mathrm{x}}\right) \\
\mathrm{Kg}\end{array}$ \\
\hline 1997 & $3,492,172.00$ & $2,253,783.00$ & $13,480.00$ & $6,500.00$ & 645 & 3.86 & 1.86 \\
\hline 1998 & $3,620,295.00$ & $2,345,951.00$ & $13,464.00$ & $6,459.00$ & 648 & 3.72 & 1.78 \\
\hline 1999 & $3,694,810.00$ & $2,360,424.00$ & $12,843.00$ & $5,955.00$ & 639 & 3.48 & 1.61 \\
\hline 2000 & $3,802,105.00$ & $2,464,550.00$ & $11,963.00$ & $5,638.00$ & 648 & 3.15 & 1.48 \\
\hline 2001 & $3,736,644.00$ & $2,412,030.00$ & $11,174.00$ & $5,290.00$ & 646 & 2.99 & 1.42 \\
\hline 2002 & $3,858,452.00$ & $2,417,327.00$ & $10,881.00$ & $5,194.00$ & 627 & 2.82 & 1.35 \\
\hline 2003 & $3,883,185.00$ & $2,438,338.00$ & $10,646.00$ & $4,532.00$ & 628 & 2.74 & 1.17 \\
\hline 2004 & $3,970,555.00$ & $2,479,971.00$ & $10,309.00$ & $4,143.00$ & 625 & 2.60 & 1.04 \\
\hline 2005 & $4,055,423.00$ & $2,536,675.00$ & $10,340.00$ & $3,961.00$ & 626 & 2.55 & 0.98 \\
\hline 2006 & $4,064,702.00$ & $2,481,829.00$ & $9,524.00$ & $3,799.00$ & 611 & 2.34 & 0.93 \\
\hline 2007 & $4,156,745.00$ & $2,539,805.00$ & $9,042.00$ & $3,650.00$ & 611 & 2.18 & 0.88 \\
\hline 2008 & $4,119,388.00$ & $2,477,213.00$ & $7,830.00$ & $3,330.00$ & 601 & 1.90 & 0.81 \\
\hline Total & $46,454,476.00$ & $29,207,896.00$ & $131,496.00$ & $58,451.00$ & 629 & 2.83 & 1.26 \\
\hline
\end{tabular}

Source: Based on EIA (US Energy Information Administration) data.

\section{Specification 1: payback time only}

The first model used in this study is the most basic, in that it includes only PB, since the preliminary analysis as per Section 2 suggests that this is a determinant variable in EE investment decisions. The model used is as follows:

$$
\psi=\beta_{0}+\beta_{1} \cdot \ln \left(P B_{i}\right)+\beta_{\mathbf{2}} \cdot \ln \left(P B_{i}\right)^{2}+\varepsilon
$$

Where payback time is defined as the cost of EE investment divided by the per annum savings that result. The results for this specification of a Probit model are shown in Table 5. As can be observed, both variables are highly significant and, as expected, negative in sign. In other words, the shorter the payback time on the investment measures suggested, the greater the tendency to invest in EE seems to be. 
Table 5

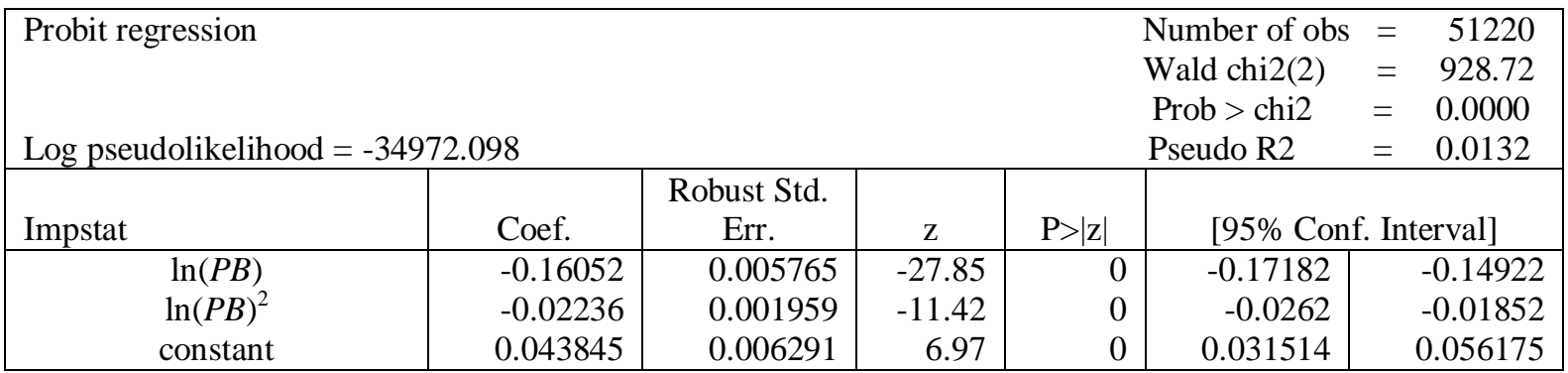

To study the sensitivity of this variable, the following equation must be defined:

$$
\frac{d \Phi}{d(\ln (P B))}=\frac{d \Phi}{\frac{d(P B)}{P B}}=\left(\beta_{1}+2 \beta_{2}\right) \cdot \emptyset(\psi)
$$

Where $\emptyset(\psi)$ is the standard normal density, obtained from:

$$
\emptyset(\psi)=\frac{1}{\sqrt{2 \pi}} e^{-\frac{\psi^{2}}{2}}
$$

The sensitivity of the probability of acceptance of investment in the face of variations in payback time is therefore given by:

$$
s=\frac{d \Phi}{d(P B)}=\frac{1}{P B}\left(\beta_{1}+2 \beta_{2}\right) . \emptyset(\psi)
$$

Note that this sensitivity depends on the PB variable. This is tantamount to stating that a given percentage decrease in PB will increase the likelihood of acceptance by different amounts depending on the initial PB.

This result suggests that policies intended to reduce payback times are bound to be effective in increasing the rate of investment in EE measures. Reductions in PB may be obtained, for instance, by subsidising investment. These points are taken into account in the policy analysis presented in the final section below.

The probability of an investment being made can be obtained from the following formula:

$$
\Phi(\psi)=\Phi\left(\beta_{0}+\beta_{1} \cdot \ln \left(P B_{i}\right)+\beta_{2} \cdot \ln \left(P B_{i}\right)^{2}\right.
$$

Like sensitivity, probability of implementation is thus shown in equation (9) to depend on PB. These two points are shown graphically in Figure 8. From this figure it can be observed that the probability of an investment being made decreases as the payback time in years increase, while sensitivity increases significantly. From a public policy viewpoint this suggests that a policy of subsidies would be most effective for those EE investments which have the shortest PBs, and 
especially for those with PBs of less than one year. As the number of years' payback time increase, the effectiveness of a lump-sum subsidy decreases gradually and significantly. This entirely intuitive result seems to be confirmed through this simple econometric estimation. The specifications below seek to enrich this analysis.

Figure 8:

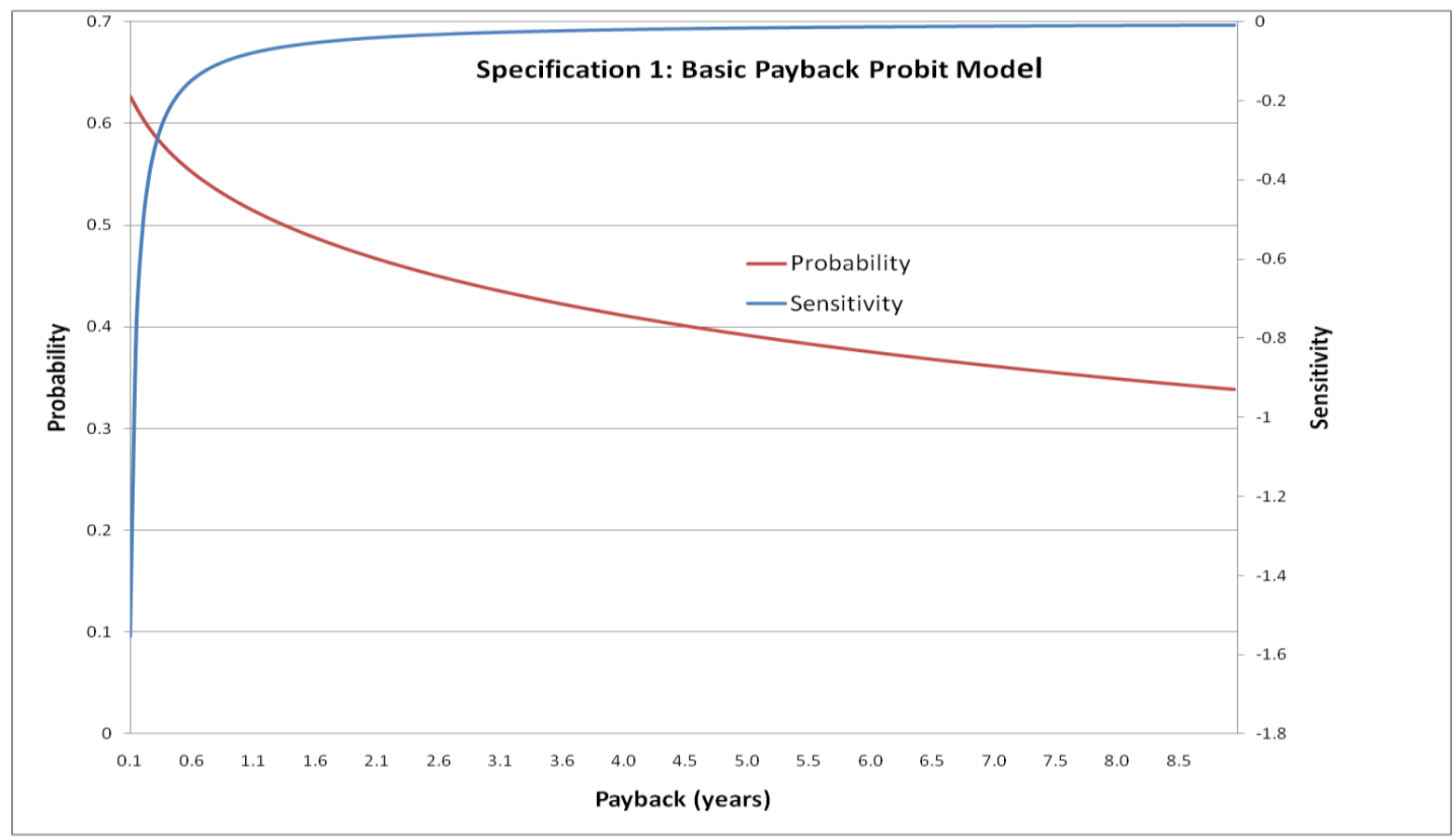

\section{Specification 2: payback time plus variables for the state where plants are located}

In this second case two further variables are considered: the GDP of the state where each manufacturing plant is located (as an indicator of the wealth of surrounding area) and the total CO2 emissions from that state (as an indicator of pollution levels in the area). The following model is obtained:

$$
\psi=\beta_{0}+\beta_{\mathbf{1}} \cdot \ln \left(P B_{i}\right)+\beta_{\mathbf{2}} \cdot \ln \left(P B_{i}\right)^{2}+\beta_{\mathbf{3}} \cdot \ln \left(G D P_{k}\right)+\beta_{\mathbf{4}} \cdot \ln \left(\mathrm{EMI}_{\mathrm{k}}\right)+\varepsilon
$$

The results shown in table 6 suggest that firms located in the states with the highest emission levels are more likely to invest in EE. By contrast, firms in the states with the highest GDPs from manufacturing industry are, paradoxically, less likely to invest in EE, all else being equal. In other words, it is in states where GDP is lowest that firms show the greatest tendency to invest in EE.

A policy recommendation that can be drawn directly from these results is that supporting measures should be most effective in those states where industrial GDP is lowest and the $\mathrm{CO} 2$ emission rate is highest. The former is reasonable as the marginal benefit of abating emissions is 
likely to be greater in those states where emissions are higher, while one could not easily explain the fact that companies in less richer states might be willing to invest more. If the possibility is considered of a future market for $\mathrm{CO} 2$ emission rights or a similar mechanism for carbon price fixing that penalises emissions, reduction measures would also result in other benefits which would be by no means negligible.

Table 6

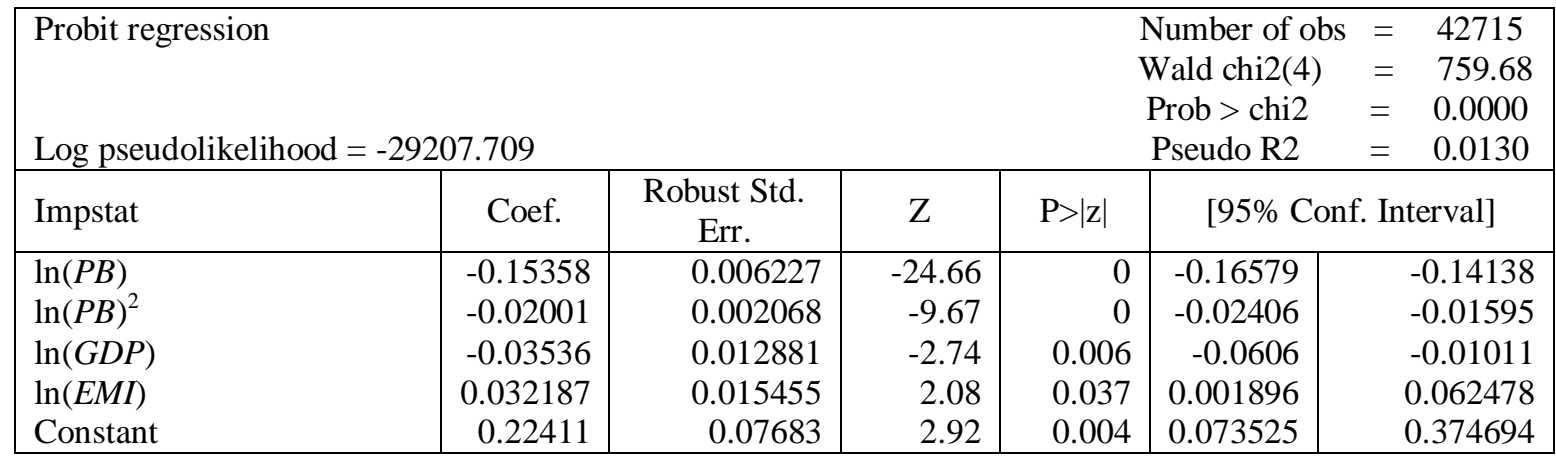

In this model the coefficients $\beta_{1}$ and $\beta_{\mathbf{z}}$ are changed, which implies changes in the sensitivity and in the probability of acceptance of a given PB in accordance with the characteristics of each state.

Figure 9: Sensitivity to GDP

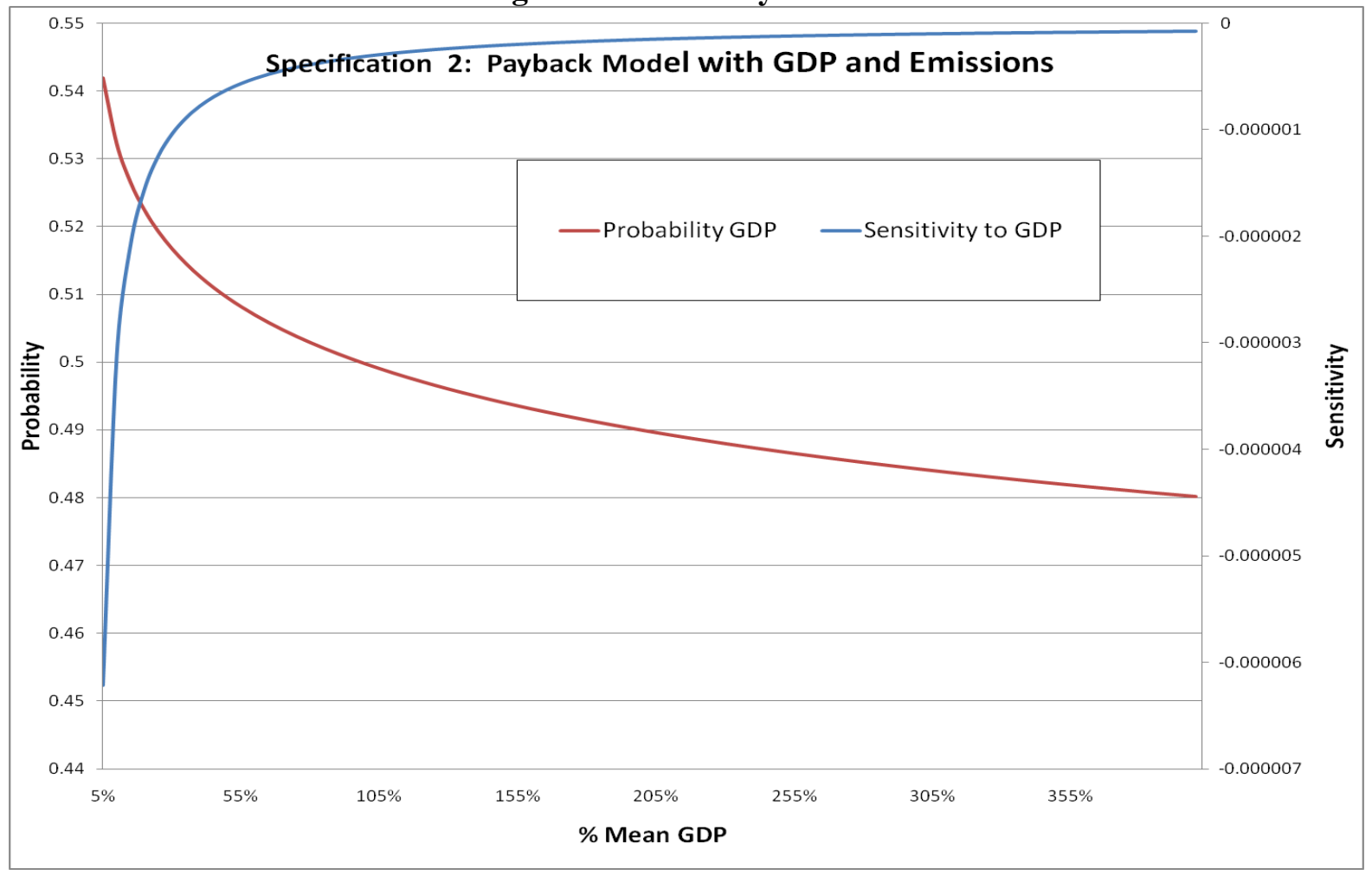


Figure 10: Sensitivity to Emissions

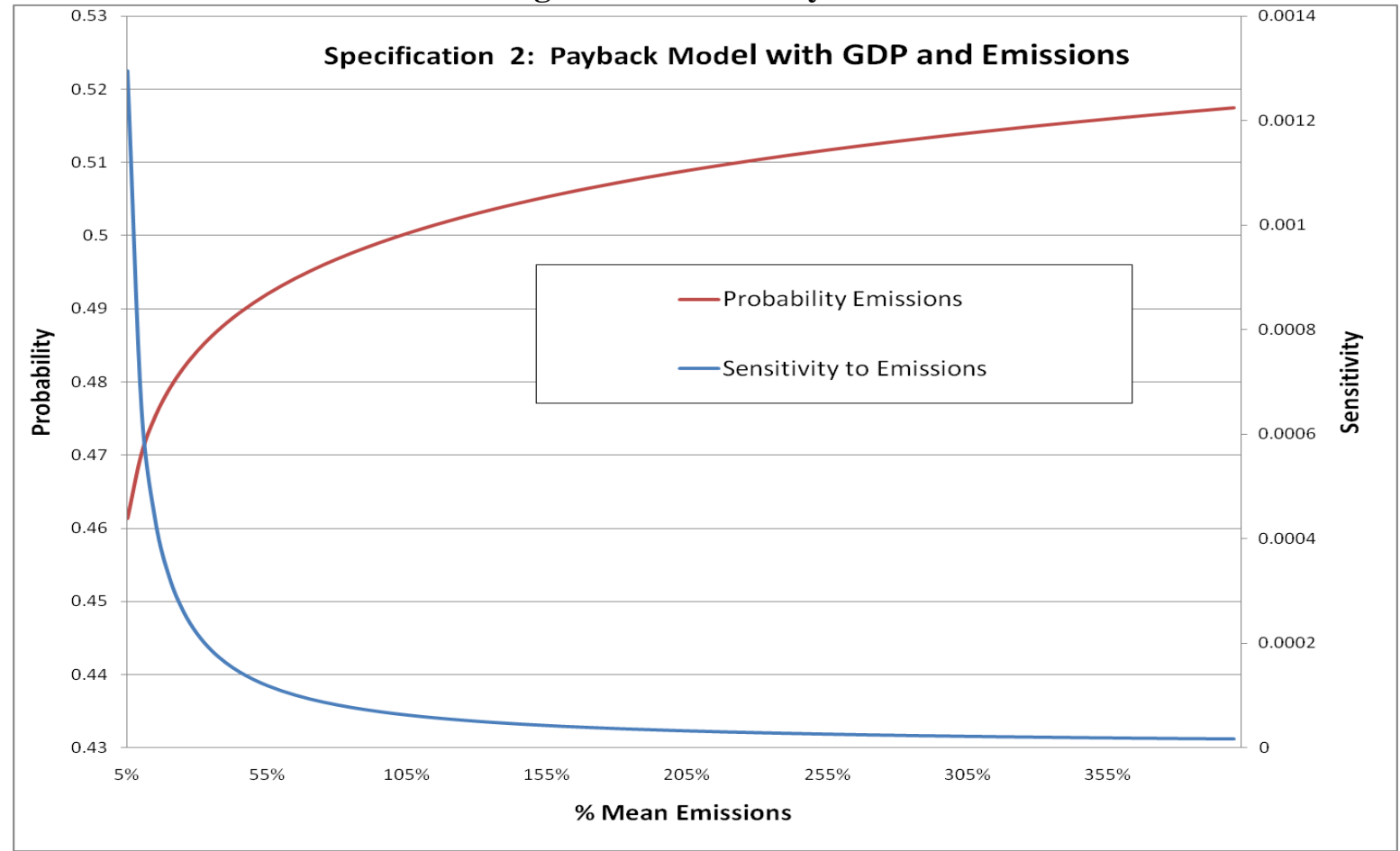

The graphs above show the probability and sensitivity levels when GDP and emissions are a percentage of their mean values for the total sample. When that percentage is 100 , the values obtained for probability are quite close to those for the case in Specification 1, when the payback time considered is the mean value, which in this case was 1,1082 .

Specification 3: payback time plus state variables, dummies for assessment centres, sectors of industry and $A R C$

$$
\begin{aligned}
\psi= & \beta_{0}+\beta_{1} \ln \left(P B_{i}\right)+\beta_{2} \ln \left(P B_{i}\right)^{2}+\beta_{3} \ln \left(G D P_{k}\right)+\beta_{4} F Y+\beta_{5} \cdot \ln \left(E M I_{k}\right)+ \\
& \overline{\text { state. }} \cdot \overline{\beta_{6}}+\overline{\text { center }} \cdot \overline{\beta_{7}}+\overline{S I C} \cdot \overline{\beta_{8}}+\overline{A R C} \cdot \overline{\beta_{9}}+\varepsilon
\end{aligned}
$$

The results obtained are shown in the table 7. When the value obtained from the dummy for a state is positive and higher than that of another state, there is a greater likelihood of recommendations being implemented in that state if the conditions of the remaining variables are equal. Of course, there may be other effects in each state reflected in other variables which may alter the results. The same applies to particular industries, participating centres and types of investment in EE. 
Table 7

\begin{tabular}{|c|c|c|c|c|c|c|}
\hline Log pseudolik & $I=-28233.0$ & & & \multicolumn{2}{|c|}{$\begin{array}{llr}\text { Number of obs } & = & 42715 \\
\text { Wald chi2(56) } & = & 2554.40 \\
\text { Prob }>\text { chi2 } & = & 0.0000 \\
\text { Pseudo R2 } & = & 0.0459\end{array}$} & \\
\hline Impstat & Coef. & Robust Std. Err. & $\mathrm{Z}$ & $\mathrm{P}>|\mathrm{z}|$ & [95\% Conf & val] \\
\hline $\ln (P B)$ & -0.13891 & 0.0065483 & -21.21 & 0 & -0.15174 & -0.12607 \\
\hline $\ln (P B)^{2}$ & -0.01663 & 0.0021296 & -7.81 & 0 & -0.0208 & -0.01245 \\
\hline $\ln (G D P)$ & -0.09546 & 0.0210359 & -4.54 & 0 & -0.13669 & -0.05423 \\
\hline Fy & -0.01405 & 0.0014248 & -9.86 & 0 & -0.01684 & -0.01125 \\
\hline $\ln (E M I)$ & 0.140324 & 0.0275568 & 5.09 & 0 & 0.086314 & 0.194334 \\
\hline California & 0.24779 & 0.0337482 & 7.34 & 0 & 0.181645 & 0.313935 \\
\hline Maine & -0.66727 & 0.1527586 & -4.37 & 0 & -0.96667 & -0.36787 \\
\hline Missouri & 0.150748 & 0.0587845 & 2.56 & 0.01 & 0.035532 & 0.265963 \\
\hline newmexico & -0.36085 & 0.1225509 & -2.94 & 0.003 & -0.60104 & -0.12065 \\
\hline northcarol a & 0.316029 & 0.0398446 & 7.93 & 0 & 0.237935 & 0.394123 \\
\hline northdakota & -0.48895 & 0.1930997 & -2.53 & 0.011 & -0.86742 & -0.11048 \\
\hline Ohio & 0.175088 & 0.0518163 & 3.38 & 0.001 & 0.07353 & 0.276646 \\
\hline southcarol a & 0.161814 & 0.0810233 & 2 & 0.046 & 0.003011 & 0.320616 \\
\hline Tennessee & 0.084223 & 0.0499136 & 1.69 & 0.092 & -0.01361 & 0.182052 \\
\hline Texas & 0.139528 & 0.0526012 & 2.65 & 0.008 & 0.036431 & 0.242624 \\
\hline Utah & -0.3172 & 0.0724917 & -4.38 & 0 & -0.45928 & -0.17512 \\
\hline Wyoming & -0.44532 & 0.2037495 & -2.19 & 0.029 & -0.84466 & -0.04598 \\
\hline Cam & 0.307153 & 0.0549704 & 5.59 & 0 & 0.199413 & 0.414893 \\
\hline Cbd & 0.081042 & 0.0354968 & 2.28 & 0.022 & 0.011469 & 0.150614 \\
\hline Cco & 0.374136 & 0.0356674 & 10.49 & 0 & 0.304229 & 0.444043 \\
\hline Cgt & 0.236764 & 0.0350902 & 6.75 & 0 & 0.167988 & 0.305539 \\
\hline $\mathrm{Cia}$ & 0.261999 & 0.0322069 & 8.13 & 0 & 0.198875 & 0.325123 \\
\hline $\mathrm{Cic}$ & 0.211747 & 0.0576858 & 3.67 & 0 & 0.098684 & 0.324809 \\
\hline $\mathrm{Cma}$ & 0.418462 & 0.0427273 & 9.79 & 0 & 0.334718 & 0.502207 \\
\hline $\mathrm{Cmi}$ & -0.27234 & 0.0578192 & -4.71 & 0 & -0.38566 & -0.15901 \\
\hline Cok & 0.174008 & 0.0362826 & 4.8 & 0 & 0.102896 & 0.245121 \\
\hline Cor & 0.48572 & 0.0414996 & 11.7 & 0 & 0.404382 & 0.567057 \\
\hline Csf & -0.14384 & 0.0390443 & -3.68 & 0 & -0.22036 & -0.06731 \\
\hline Csu & 0.445118 & 0.0564879 & 7.88 & 0 & 0.334404 & 0.555832 \\
\hline $\mathrm{Ctt}$ & -0.31662 & 0.1667725 & -1.9 & 0.058 & -0.64349 & 0.010246 \\
\hline Cud & 0.150196 & 0.0581603 & 2.58 & 0.01 & 0.036203 & 0.264188 \\
\hline Cum & 0.133807 & 0.0432853 & 3.09 & 0.002 & 0.048969 & 0.218644 \\
\hline Cwv & 0.420125 & 0.0382611 & 10.98 & 0 & 0.345135 & 0.495116 \\
\hline Car & 0.632758 & 0.0491688 & 12.87 & 0 & 0.536389 & 0.729127 \\
\hline $\mathrm{Cds}$ & 0.375129 & 0.0607715 & 6.17 & 0 & 0.256019 & 0.494239 \\
\hline $\mathrm{Cku}$ & 0.194164 & 0.0455336 & 4.26 & 0 & 0.10492 & 0.283408 \\
\hline Cme & 0.993715 & 0.1544203 & 6.44 & 0 & 0.691057 & 1.296373 \\
\hline Cmo & 0.189721 & 0.0672137 & 2.82 & 0.005 & 0.057984 & 0.321457 \\
\hline Cul & -0.41333 & 0.0809364 & -5.11 & 0 & -0.57197 & -0.2547 \\
\hline $\operatorname{sic} 20$ & 0.066217 & 0.0205471 & 3.22 & 0.001 & 0.025945 & 0.106488 \\
\hline $\operatorname{sic} 21$ & 0.494637 & 0.2625326 & 1.88 & 0.06 & -0.01992 & 1.009191 \\
\hline $\operatorname{sic} 25$ & 0.101501 & 0.0393484 & 2.58 & 0.01 & 0.02438 & 0.178623 \\
\hline $\operatorname{sic} 29$ & 0.191492 & 0.0672219 & 2.85 & 0.004 & 0.05974 & 0.323245 \\
\hline $\operatorname{sic} 32$ & 0.072094 & 0.0347473 & 2.07 & 0.038 & 0.003991 & 0.140197 \\
\hline $\operatorname{sic} 33$ & 0.048945 & 0.0262843 & 1.86 & 0.063 & -0.00257 & 0.100461 \\
\hline $\operatorname{sic} 34$ & 0.045435 & 0.0197197 & 2.3 & 0.021 & 0.006785 & 0.084085 \\
\hline $\operatorname{sic} 35$ & 0.085272 & 0.0217843 & 3.91 & 0 & 0.042576 & 0.127969 \\
\hline $\operatorname{sic} 37$ & 0.153844 & 0.0282918 & 5.44 & 0 & 0.098393 & 0.209295 \\
\hline $\operatorname{arc} 21$ & -0.48171 & 0.0927528 & -5.19 & 0 & -0.6635 & -0.29992 \\
\hline $\operatorname{arc} 22$ & -0.25304 & 0.0403388 & -6.27 & 0 & -0.33211 & -0.17398 \\
\hline $\operatorname{arc} 23$ & -0.19913 & 0.0411753 & -4.84 & 0 & -0.27983 & -0.11842 \\
\hline $\operatorname{arc} 24$ & 0.280637 & 0.0304578 & 9.21 & 0 & 0.220941 & 0.340334 \\
\hline $\operatorname{arc} 25$ & -0.39904 & 0.1304271 & -3.06 & 0.002 & -0.65467 & -0.14341 \\
\hline $\operatorname{arc} 27$ & 0.098462 & 0.030886 & 3.19 & 0.001 & 0.037927 & 0.158998 \\
\hline $\operatorname{arc} 28$ & -0.3014 & 0.080856 & -3.73 & 0 & -0.45988 & -0.14293 \\
\hline $\operatorname{arc} 29$ & -1.08338 & 0.3054871 & -3.55 & 0 & -1.68213 & -0.48464 \\
\hline$\beta_{0}($ costant $)$ & 28.01212 & 2.821074 & 9.93 & 0 & 22.48292 & 33.54132 \\
\hline
\end{tabular}




\section{Specification 4: with cost and benefit}

A model showing the cost and benefit of investing in energy efficiency is estimated below:

$$
\psi=\beta_{0}+\beta_{1} \cdot \ln (\operatorname{COST})+\beta_{\mathbf{2}} \cdot \ln (B E N)+\varepsilon
$$

The results in table 8 show that the cost factor has a greater impact on investment decisions than the potential medium and long-term benefits. This result is consistent with the findings of other studies, under the so-called "energy efficiency paradox". Similar behaviour has even been observed among individual consumers when they choose the energy efficiency level of their domestic appliances (Markandya et al, 2009). From a public policy viewpoint it seems advisable, therefore, to focus on this issue through policies to support reductions in investment costs (subsidies for investments, tax deductions, cheaper loans, etc) as opposed to longer term policies that focus on increasing the benefits from investment (increases in energy prices or carbon pricing, for example).

The effects of different combinations of investment cost with annual savings can be observed. Logically, the probabilities are highest in cases where there are both considerable savings and low EE investment costs. However, even with these highly favourable combinations the probability of acceptance does not exceed $70 \%$.

This model can also be represented by a three-dimensional graph (Figure 12).

Table 8:

\begin{tabular}{|c|c|c|c|c|c|c|}
\hline \\
\hline \multicolumn{4}{|c|}{ Probit regression } & \multicolumn{3}{|c|}{$\begin{array}{l}\text { Number of obs }=42715 \\
\text { Wald chi2 }(4)=759.68 \\
\text { Prob }>\text { chi } 2=0.0000\end{array}$} \\
\hline \multicolumn{4}{|c|}{ Log pseudolikelihood $=-29207.709$} & Pseud & R2 & 0.0130 \\
\hline Impstat & Coef. & Robust Std. Err. & $\mathrm{z}$ & $\mathrm{P}>|\mathrm{z}|$ & \multicolumn{2}{|c|}{ [95\% Conf. Interval] } \\
\hline $\ln (P B)$ & -0.15358 & 0.006227 & -24.66 & 0 & -0.16579 & -0.14138 \\
\hline $\ln (P B)^{2}$ & -0.02001 & 0.002068 & -9.67 & 0 & -0.02406 & -0.01595 \\
\hline $\ln (G D P)$ & -0.03536 & 0.012881 & -2.74 & 0.006 & -0.0606 & -0.01011 \\
\hline $\ln (E M I)$ & 0.032187 & 0.015455 & 2.08 & 0.037 & 0.001896 & 0.062478 \\
\hline constant & 0.22411 & 0.07683 & 2.92 & 0.004 & 0.073525 & 0.374694 \\
\hline
\end{tabular}


Figure 11: Sensitivity to Cost and Benefit

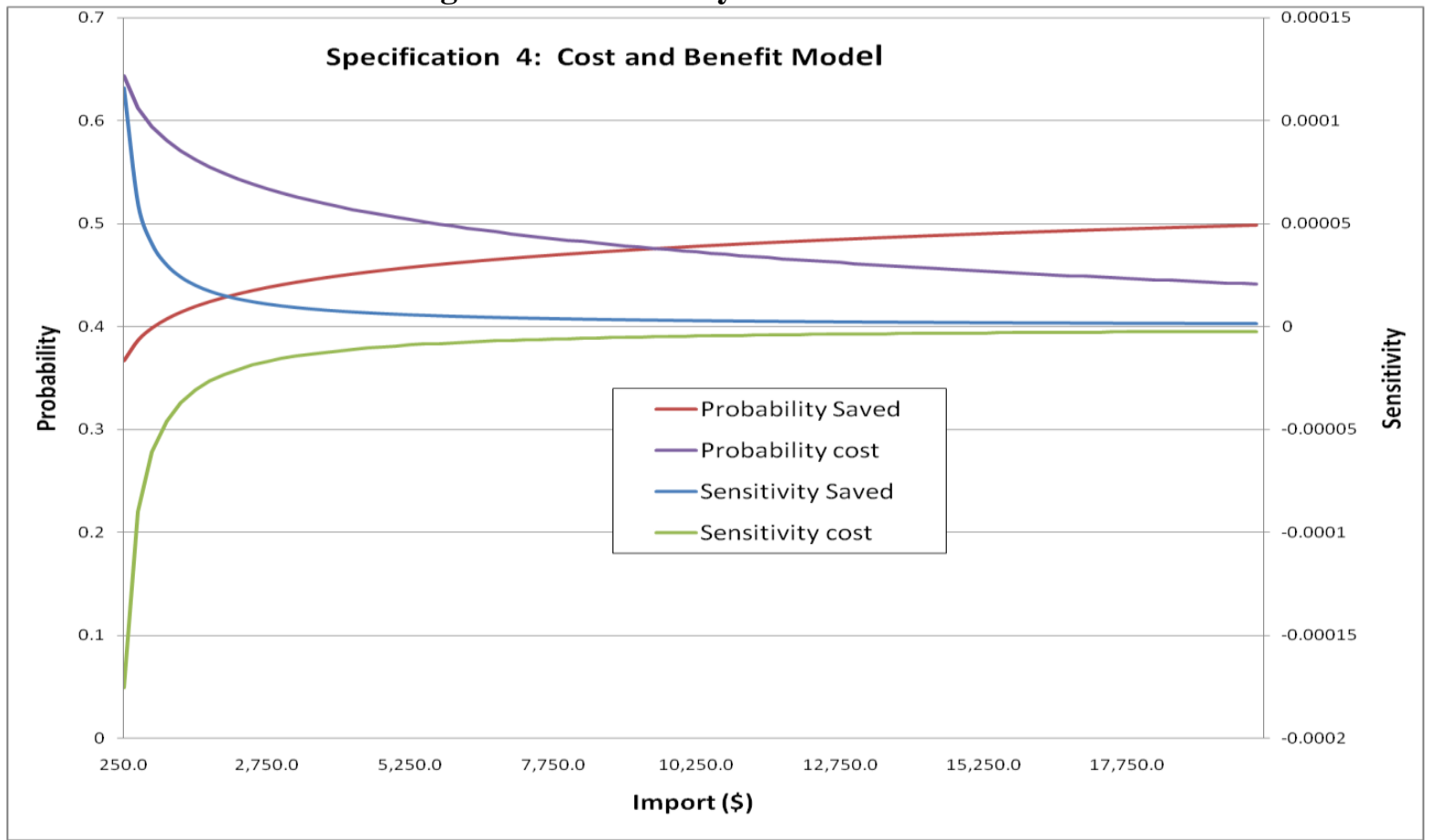

Figure 12:

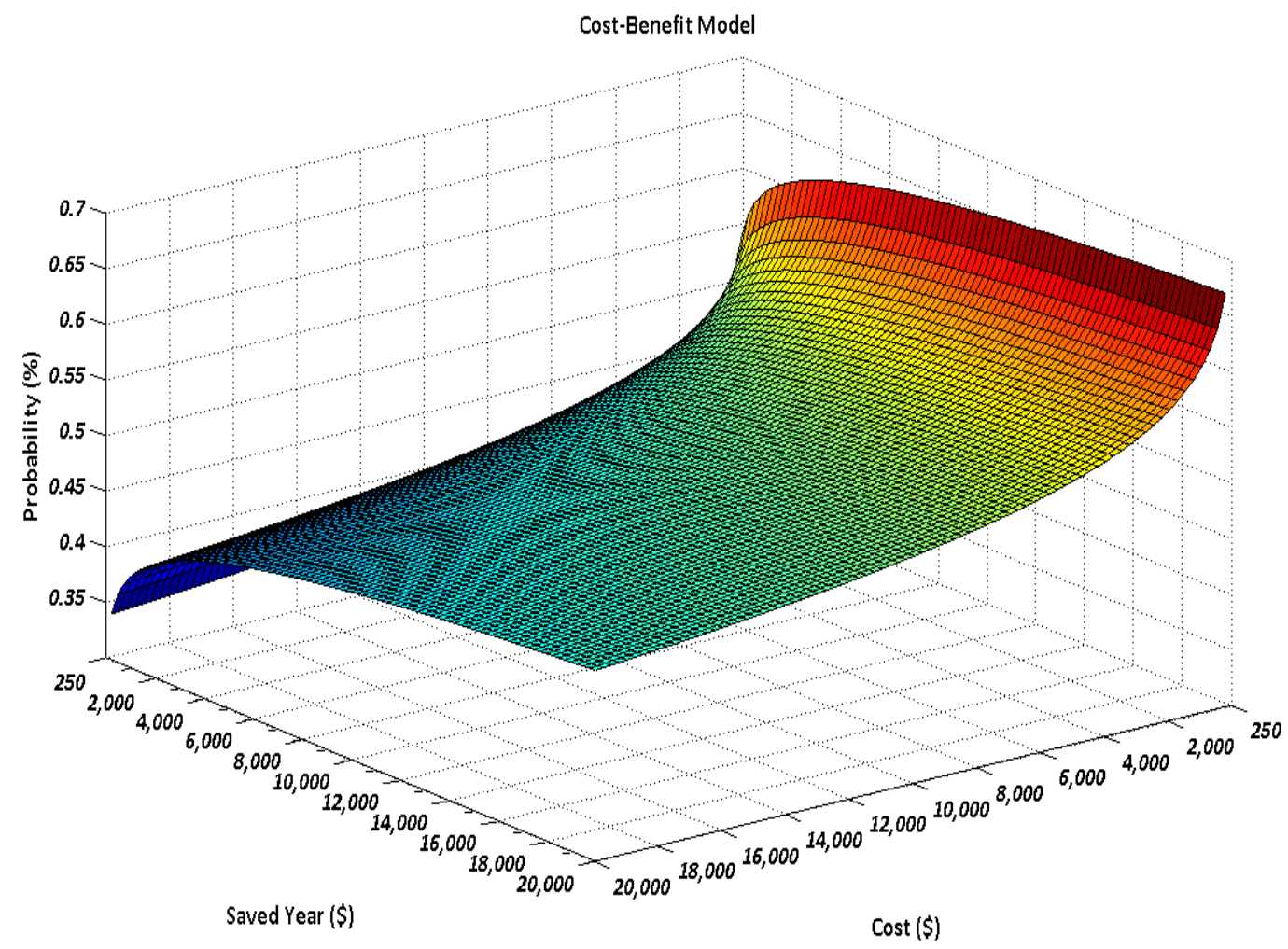




\section{Specification 5: with cost, benefit and years}

This model estimates the influence of the passage of time on the probability of an EE measure being accepted. The following is obtained: the coefficient $\beta_{3}$ is negative and significant (table 9). It shows a level of depletion in the effectiveness of the EE improvement programme, perhaps due to the best opportunities already having been taken, as mentioned in some of the intuitions in Section 2 above.

$$
\psi=\beta_{0}+\beta_{1} \cdot \ln (C O S T)+\beta_{\mathbf{2}} \cdot \ln (B E N)+\beta_{3} \cdot \ln (Y E A R)+\varepsilon
$$

Table 9

\begin{tabular}{|c|c|c|c|c|c|c|c|}
\hline \multicolumn{4}{|c|}{ Probit regression } & \multicolumn{2}{|c|}{$\begin{array}{l}\text { Number of obs } \\
\text { Wald chi2(3) } \\
\text { Prob > chi2 } \\
\text { Pseudo R2 }\end{array}$} & $\begin{array}{l}= \\
= \\
= \\
=\end{array}$ & $\begin{array}{c}50944 \\
1118.51 \\
0.0000 \\
0.0168 \\
\end{array}$ \\
\hline Impstat & Coef. & $\begin{array}{l}\text { Robust Std. } \\
\text { Err. }\end{array}$ & $\mathrm{Z}$ & $\mathrm{P}>|\mathrm{z}|$ & \multicolumn{3}{|c|}{ [95\% Conf. Interval] } \\
\hline$\overline{\ln (C O S T)}$ & -0.11823 & 0.004127 & -28.65 & 0 & -0.126 & & -0.11014 \\
\hline $\ln (B E N)$ & 0.089941 & 0.005246 & 17.15 & 0 & 0.0796 & & 0.100222 \\
\hline $\ln$ (Year) & -29.9548 & 1.841508 & -16.27 & 0 & -33.56 & & -26.3455 \\
\hline constant & 227.8829 & 13.98914 & 16.29 & 0 & 200.46 & & 255.3011 \\
\hline
\end{tabular}

Figure 13

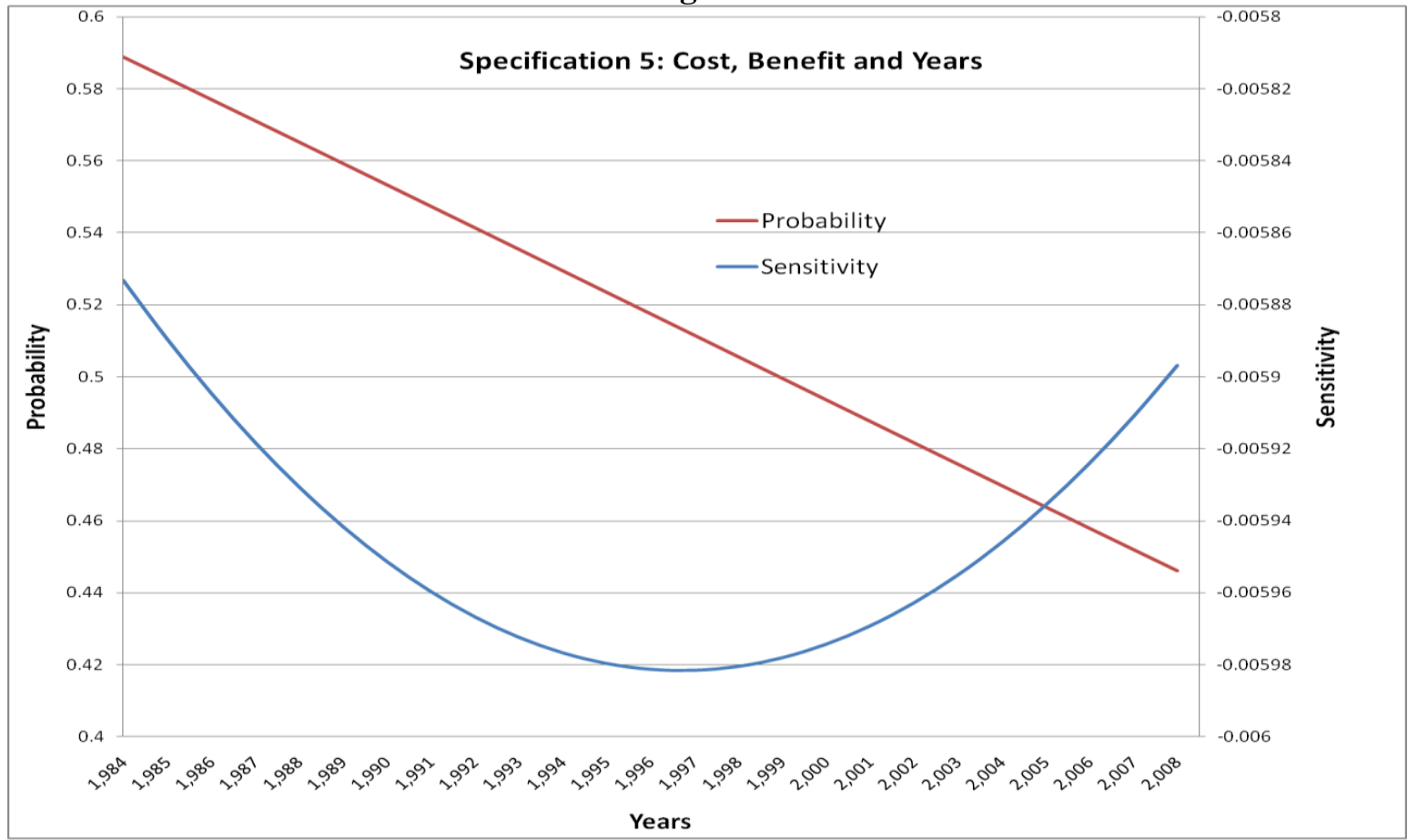


This model shows costs, benefits, the GDP of the state where the plant is located and the emissions from that state:

$$
\psi=\beta_{0}+\beta_{\mathbf{1}} \cdot \ln (C O S T)+\beta_{\mathbf{2}} \cdot \ln (B E N)+\beta_{0} \cdot \ln (G D P)+\beta_{\mathbf{4}} \cdot \ln (E M I)+\varepsilon
$$

The results are in table 10. The graphs in figure 14 show that the results for cost and benefit are similar to those for payback time: a decrease in costs leads to a large increase in the probability of an EE investment project being accepted. An increase in annual savings is also an important factor, but its impact is not so great. The $\mathrm{x}$-axis on the graph shows cost and benefit amounts as percentages of the mean of the sample for all the firms considered.

Table 10

\begin{tabular}{|c|c|c|c|c|c|c|c|}
\hline \\
\hline \multirow{3}{*}{\multicolumn{4}{|c|}{ Probit regression }} & \multirow{2}{*}{\multicolumn{3}{|c|}{$\begin{array}{l}\text { Number of obs }= \\
\text { Wald chi2(4) }\end{array}$}} & 42514 \\
\hline & & & & & & & 687.01 \\
\hline & & & & \multicolumn{2}{|c|}{ Prob $>$ chi 2} & $=$ & 0.0000 \\
\hline \multicolumn{4}{|c|}{ Log pseudolikelihood $=-29080.508$} & Pse & o R2 & $=$ & 0.0124 \\
\hline impstat & Coef. & Robust Std. Err. & $\mathrm{Z}$ & $\mathrm{P}>|\mathrm{z}|$ & \multicolumn{3}{|c|}{ [95\% Conf. Interval] } \\
\hline $\ln (C O S T)$ & -0.11366 & 0.004458 & -25.5 & 0 & -0.12 & & -0.10492 \\
\hline $\ln (B E N)$ & 0.082715 & 0.005659 & 14.62 & 0 & 0.0716 & & 0.093807 \\
\hline $\ln (G D P)$ & -0.03282 & 0.012928 & -2.54 & 0.011 & -0.058 & & -0.00748 \\
\hline $\ln (E M I)$ & 0.034495 & 0.0155 & 2.23 & 0.026 & 0.0041 & & 0.064874 \\
\hline constant & 0.401574 & 0.081071 & 4.95 & 0 & 0.2426 & & 0.56047 \\
\hline
\end{tabular}

Figure 14

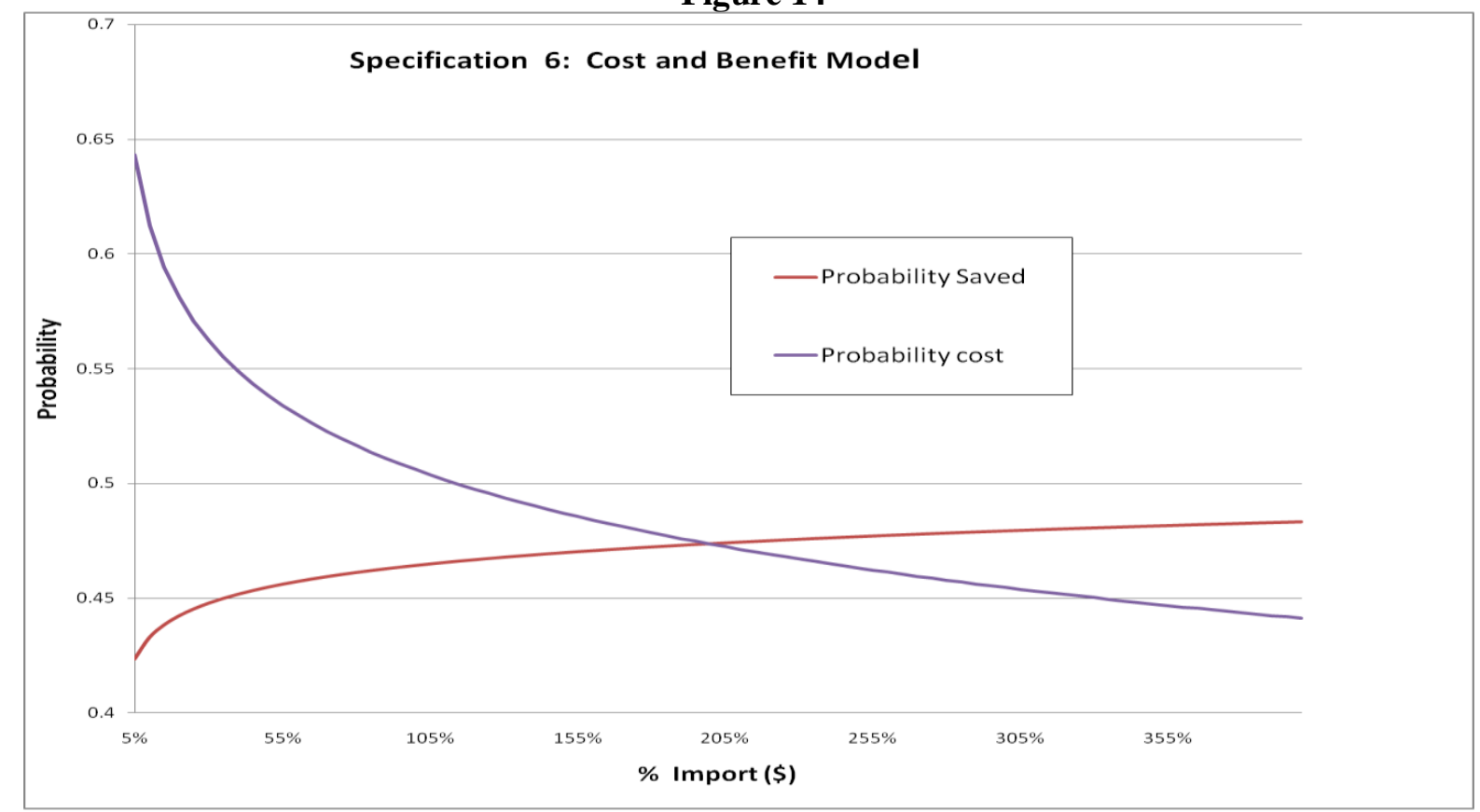


Specification 7: with cost, benefit, state variables and dummies

$$
\begin{gathered}
\psi=\beta_{0}+\beta_{1} \cdot \ln (\operatorname{Cost})+\beta_{2} \cdot \ln (\text { Ben })^{2}+\beta_{3} \cdot \ln (G D P)+\beta_{4} \cdot F Y+\beta_{5} \cdot \ln (\text { EMI })+ \\
\text { state } \cdot \overline{\beta_{6}}+\overline{\text { center }} \cdot \overline{\beta_{7}}+\overline{\text { SIC }} \cdot \overline{\beta_{8}}+\overline{A R C} \cdot \overline{\beta_{9}}+\varepsilon
\end{gathered}
$$

\begin{tabular}{|c|c|c|c|c|c|c|}
\hline Probit regress & & & & \multicolumn{2}{|c|}{$\begin{array}{l}\text { Number of obs } \\
\text { Wald chi2(52) } \\
\text { Prob > chi2 } \\
\text { Pseudo R2 }\end{array}$} & $\begin{array}{ll}= & 42514 \\
= & 2356.45 \\
= & 0.0000 \\
= & 0.0430\end{array}$ \\
\hline Impstat & Coef. & Robust Std. Err. & $\mathrm{z}$ & $\mathrm{P}>|\mathrm{z}|$ & \multicolumn{2}{|c|}{ [95\% Conf. Interval] } \\
\hline $\ln (C O S T)$ & -0.09681 & 0.004768 & -20.31 & 0 & -0.10616 & \begin{tabular}{l|l}
5 & -0.08747
\end{tabular} \\
\hline $\ln (B E N)$ & 0.086812 & 0.005948 & 14.59 & 0 & 0.075154 & 0.09847 \\
\hline $\ln (G D P)$ & -0.0728 & 0.022487 & -3.24 & 0.001 & -0.11687 & -0.02873 \\
\hline $\ln (E M I)$ & 0.082751 & 0.032041 & 2.58 & 0.01 & 0.019952 & 0.145549 \\
\hline California & 0.286155 & 0.034831 & 8.22 & 0 & 0.217887 & 0.354423 \\
\hline Maine & -0.63596 & 0.152735 & -4.16 & 0 & -0.93532 & -0.33661 \\
\hline Missouri & 0.130994 & 0.058517 & 2.24 & 0.025 & 0.016303 & 0.245685 \\
\hline Newmexico & -0.44021 & 0.121918 & -3.61 & 0 & -0.67916 & -0.20125 \\
\hline northcarol a & 0.295689 & 0.039075 & 7.57 & 0 & 0.219103 & 0.372275 \\
\hline Northdakota & -0.53814 & 0.193904 & -2.78 & 0.006 & -0.91818 & -0.15809 \\
\hline Ohio & 0.170161 & 0.051805 & 3.28 & 0.001 & 0.068625 & 0.271697 \\
\hline Texas & 0.203734 & 0.057694 & 3.53 & 0 & 0.090656 & 0.316812 \\
\hline Utah & -0.3957 & 0.072013 & -5.49 & 0 & -0.53684 & -0.25456 \\
\hline Cam & 0.325418 & 0.055085 & 5.91 & 0 & 0.217453 & 0.433383 \\
\hline $\mathrm{Cbd}$ & 0.068924 & 0.036065 & 1.91 & 0.056 & -0.00176 & 0.13961 \\
\hline Cco & 0.367916 & 0.035995 & 10.22 & 0 & 0.297367 & 0.438466 \\
\hline $\mathrm{Cgt}$ & 0.251082 & 0.035312 & 7.11 & 0 & 0.181871 & 0.320292 \\
\hline $\mathrm{Cia}$ & 0.230898 & 0.031977 & 7.22 & 0 & 0.168224 & 0.293572 \\
\hline $\mathrm{Cic}$ & 0.135649 & 0.057453 & 2.36 & 0.018 & 0.023043 & 0.248254 \\
\hline Cll & 0.374912 & 0.052714 & 7.11 & 0 & 0.271594 & 0.478229 \\
\hline $\mathrm{Cma}$ & 0.366236 & 0.042281 & 8.66 & 0 & 0.283367 & 0.449104 \\
\hline $\mathrm{Cmi}$ & -0.33423 & 0.059953 & -5.57 & 0 & -0.45174 & -0.21673 \\
\hline Cok & 0.17047 & 0.037532 & 4.54 & 0 & 0.096908 & 0.244031 \\
\hline Cor & 0.436171 & 0.041089 & 10.62 & 0 & 0.355639 & 0.516703 \\
\hline Csf & -0.17969 & 0.039012 & -4.61 & 0 & -0.25615 & -0.10322 \\
\hline Csu & 0.369964 & 0.056194 & 6.58 & 0 & 0.259826 & 0.480103 \\
\hline $\mathrm{Ctt}$ & -0.31345 & 0.17038 & -1.84 & 0.066 & -0.64739 & 0.020491 \\
\hline Cua & -0.31308 & 0.171901 & -1.82 & 0.069 & -0.65 & 0.02384 \\
\hline Cud & 0.150231 & 0.059439 & 2.53 & 0.011 & 0.033733 & 0.266729 \\
\hline Cuf & 0.06981 & 0.037359 & 1.87 & 0.062 & -0.00341 & 0.143032 \\
\hline Cum & 0.120944 & 0.043454 & 2.78 & 0.005 & 0.035775 & 0.206112 \\
\hline Cwv & 0.413434 & 0.040145 & 10.3 & 0 & 0.334752 & 0.492117 \\
\hline Car & 0.659539 & 0.04924 & 13.39 & 0 & 0.56303 & 0.756048 \\
\hline $\mathrm{Cku}$ & 0.245366 & 0.045335 & 5.41 & 0 & 0.156512 & 0.334221 \\
\hline Cme & 0.921032 & 0.154905 & 5.95 & 0 & 0.617423 & 1.224641 \\
\hline $\mathrm{Cds}$ & 0.363781 & 0.0604 & 6.02 & 0 & 0.245399 & 0.482162 \\
\hline $\mathrm{Cmo}$ & 0.247316 & 0.066673 & 3.71 & 0 & 0.116639 & 0.377993 \\
\hline $\mathrm{Cul}$ & -0.39772 & 0.082101 & -4.84 & 0 & -0.55864 & -0.23681 \\
\hline $\operatorname{sic} 20$ & 0.043976 & 0.020054 & 2.19 & 0.028 & 0.00467 & 0.083281 \\
\hline $\operatorname{sic} 21$ & 0.435991 & 0.258138 & 1.69 & 0.091 & -0.06995 & 0.941933 \\
\hline $\operatorname{sic} 25$ & 0.078751 & 0.038822 & 2.03 & 0.043 & 0.002661 & 0.154841 \\
\hline $\operatorname{sic} 29$ & 0.153813 & 0.068846 & 2.23 & 0.025 & 0.018877 & 0.28875 \\
\hline $\operatorname{sic} 35$ & 0.059218 & 0.021157 & 2.8 & 0.005 & 0.01775 & 0.100685 \\
\hline $\operatorname{sic} 37$ & 0.11623 & 0.027806 & 4.18 & 0 & 0.061731 & 0.170729 \\
\hline $\operatorname{arc} 21$ & -0.49468 & 0.092394 & -5.35 & 0 & -0.67577 & -0.31359 \\
\hline $\operatorname{arc} 22$ & -0.26159 & 0.040379 & -6.48 & 0 & -0.34073 & -0.18245 \\
\hline $\operatorname{arc} 23$ & -0.21376 & 0.041568 & -5.14 & 0 & -0.29523 & -0.13229 \\
\hline $\operatorname{arc} 24$ & 0.263009 & 0.030505 & 8.62 & 0 & 0.20322 & 0.322797 \\
\hline $\operatorname{arc} 25$ & -0.4226 & 0.129612 & -3.26 & 0.001 & -0.67663 & -0.16856 \\
\hline $\operatorname{arc} 27$ & 0.075689 & 0.030941 & 2.45 & 0.014 & 0.015045 & 0.136333 \\
\hline $\operatorname{arc} 28$ & -0.33857 & 0.08137 & -4.16 & 0 & -0.49805 & -0.17909 \\
\hline $\operatorname{arc} 29$ & -1.27075 & 0.307321 & -4.13 & 0 & -1.87309 & -0.66841 \\
\hline Constant & 0.082895 & 0.131656 & 0.63 & 0.529 & -0.17515 & 0.340936 \\
\hline
\end{tabular}

Table 11 


\section{Further research}

There are many interesting factors that have been highlighted in this paper that deserve further investigation in coming contributions. Parallel to this analysis some efforts have been done to further unravel the relationship among the propensity to invest in energy efficiency and the environmental stringency in the States where companies are located. This approach has been developed by the use of the Industry Adjusted Index of State Environmental Compliance Cost (Levinson, 2001). Unfortunately the index only covers the period from 1977 to 1994 and has been outside the scope of this paper to update it. In any case, some preliminary regressions have been run for the 1984-1994 period with more than 15,600 observations out of the total 60,463 of the database used on this paper. Although a deeper analysis is granted, existing results show that the index is significant and has the correct positive sign in most of the specifications ${ }^{9}$.

\section{Policy Implications and Conclusions}

The rate of investment in energy efficiency measures continues to be a core part of any energy policy, particularly in a context in which environmental variables (especially climate change) are increasingly important. No public policy manager or employer can reject the potential scope for improvement that EE policies continue to offer. Indeed, the package of energy and climate change measures proposed by the European Union, $20-20-20^{10}$ and the well-known Waxman-Markey bill for dealing with climate change in the United States envisage energy efficiency as one of the chief instruments for reducing $\mathrm{CO} 2$ emissions. This paper provides additional information which is highly relevant for the optimal design of energy efficiency support policies, based on the results of a programme that has been up and running in the USA for over 30 years and behaviour patterns shown by firms.

A preliminary analysis of the raw data suggests that along with other temporary effects which are difficult to determine there is also, as might be expected, a depletion effect in investment opportunities. In other words the best investments are made first and less attractive measures are left for later. The investment implementation rate is relatively low for the total number of recommendations made. This probably indicates that the recommendations made are not as suitable as they could be, that other factors exist which are judged to be more important than these recommendations when it comes to deciding whether or not to invest, or a combination of the two.

There is also clear evidence from econometric models in support of the idea that the payback time variable is determinant in investment decisions, as might be expected. Investment cost is also highly important.

\footnotetext{
${ }^{9}$ Preliminary regressions are available from the authors upon request.

${ }^{10}$ Gallastegui and Galarraga (2010) (8).
} 
In addition, the following main conclusions can be drawn from the two families of models used in this study (payback time and cost/benefit):

1. Changes in payback time have a non-linear influence on investment decisions, so the tendency is different depending on the times involved.

2. The probability of an investment being made in years decreases as the payback time in years increases, while sensitivity increases significantly.

3. Firms located in the states with the highest levels of GHG emissions are more likely to invest in EE. And, according to preliminary results, also those with more stringent environmental legislation.

4. Firms located in the states where GDP from manufacturing industry is highest are less likely to invest in $\mathrm{EE}$.

5. Investment cost has more influence on investment decisions than potential benefits.

6. Logically, the rate of investment in EE is highest when considerable savings (or benefits) may be expected from low-cost investments, but there is a ceiling of $70 \%$ which is not easily exceeded even when these two favourable factors combine.

7. Both reductions in costs and increases in expected savings increase the likelihood of an EE investment project being accepted, though the impact of the latter is lower.

When it comes to offering recommendations on policy design, the need to study in greater depth the context in which investments take place cannot be obviated; other aspects that must be assessed include behaviour patterns, the availability of loans and other financial factors that may influence decisions. Even so, the results presented here offer intuitions which are most useful to policy-makers.

Particularly noteworthy is the importance of payback time compared to other variables, especially in investments with payback times of less than one year. The link between this variable and the soundness of the teams of recommenders may merit a more thorough investigation, but it lies outside the scope of this study. Therefore, any policy that directly or indirectly helps to reduce payback time must initially be seen as an option worth bearing in mind. As payback time increases the effectiveness of policies gradually decreases, so it can also be asserted that measures affecting shorter payback times will be more efficient than those affecting longer payback times. For the latter more specific, nuanced policies may be preferable.

The GDP of the industry where measures are to be implemented is another important variable to be considered. Perhaps counter intuitively, firms located in geographical areas where aggregate output is lower are found to be more likely to invest as a result of the programme. This greater likelihood to accept support among industries in areas with lower sectoral GDPs may be a clear reflection that such firms are in greater need of support than others whose results are better. Likewise, firms in states where GHG emission levels are highest are found to be more likely to invest as per the recommendations made under the programme. In other words, in terms of both actual needs 
for support and sensitivity to changes in behaviour as a result of policies, regions with low or sectoral GDPs and higher emission levels should be targeted on a priority basis by public sector policies.

Given that cost seems to outweigh potential benefits as a factor in deciding whether to make an investment, policies that focus on cost should be more effective in getting firms to make investments in energy efficiency. Instruments such as tax deductions, direct subsidies, cheaper loans and taxes on pollution-causing activities seem to be the best options to encourage energy efficiency in specific areas of activity. Instruments that focus on future savings, such as carbon pricing and energy pricing policies, are likely to be less useful in achieving this objective. This apparent paradox suggests that along with the proven need for worldwide carbon pricing policies (Neuhoff, 2008), measures to help reduce the total cost of investment rather than the relative cost continue to be essential, and above all highly effective, in supporting certain industries and sectors. The well-known short-termism effect (which, as mentioned above, can be seen even among individuals) is also observable in industrial activities (Graham et al, 2005). A detailed analysis of the actual discount rates applied in these industrial sectors might shed more light on this matter.

Finally, the depletion effect and the apparent existence of an investment ceiling (found here to be around 70\%) suggest that policies of this type should be reassessed regularly to gauge their actual impact and make any adjustments that may be needed to ensure their continued effectiveness.

The findings of the study presented here are consistent with those of Anderson and Newell (2004) though our sample differs significantly from theirs: we focus on measures concerned with electricity and use data on a 25 year period from 1984 to 2008, while they consider general measures that include other savings, such as particular fuels, using data on the period from 1981 to 2000. Our study also considers other factors such as regional variables (at state level), assessment centres and trends over time. Rather than assessing the decision-making models of firms, we take them as given and focus on those energy policy measures that could be taken which would have the greatest effect, since firms behave in the way revealed by the database. In particular, we look in depth at the sensitivity of the implementation rate to changes in the various variables considered.

\section{References}

Anderson, S. T. and Newell, R. G. (2004), "Information Programs for Technology Adoption: The Case of Energy-Efficiency Audits". Resource and Energy Economics, page 26 pp. 27-50.

Tonn, B. and y Martín, M. (2000), “Industrial Energy Efficiency Decision Making”. Energy Policy, 28(12), pp 831-843.

Dobbs, I. M. (2009), "How Bad Can Short Terminism Be?-A Study of The Consequences of High Hurdle Discount Rates and Low Payback Thresholds". Management Accounting Research, 20, pp. 117-128. 
IEA (2009), "Implementing Energy Efficiency Policies: Are IEA Member Countries on Track?", OECD/IEA, Paris.

Jaffe, A.B., Newell, R.G. and Stavins, R.N. (2004), "Economics of Energy Efficiency”, Encyclopedia of Energy, 2, 79-90.

Gallastegui, M. C. and Galarraga, I. (2010), "La Unión Europea Frente al Cambio Climático: E1 Paquete de Medidas sobre Cambio Climático y Energía (20-20-20), in Becker, F., Cazorla, L. M. and Martínez-Simancas, J. (eds), Tratado de Energías Renovables, IberdrolaThomson-Aranzadi.

Graham, J.R., Harvey, C.R. (2001), “The Theory and Practice of Corporate Finance: Evidence From the Field". Journal of Financial Economics, 60, 187-243.

Graham, J. R., Harvey, C. R. and Rajgopal, S. (2005), "The Economic Implications of Corporate Financial reporting". Journal of Accounting and Economics, 40: 3-73.

Levinson, A, (2001), “An Industry-Adjusted Index of State Environmental Compliance Cost" in Carraro, C. and Metcalf, G. E. (eds), "Behavioral and Distributional Effects of Environmental Policy", University of Chicago Press. ISBN: 0-226-09481-2

Linares, P. and Labandeira, X., (2010), "Energy Efficiency: Economics and Policy". Journal of Economic Surveys, forthcoming (2010).

Neuhoff, K. (2008), “Tackling Carbon: How to Price Carbon for Climate Policy”, Report by Climate Strategies, Faculty of Economics, University of Cambridge, 2008.

Markandya, A.; Ortiz, R.A.; Mudgal, S. and Tinetti, B. (2009), "Analysis of tax Incentives for Energy-Efficient Durables in the EU”. Energy Policy, 37, pp. 5662-5674.

Muthulingam, S., Corbett, C. J., Benartzi, S. and Oppenheim, B. (2009), "Managerial Biases and Energy Saving: an Empirical Analysis of the Adoption of Process Improvement Recommendations". Working Paper UCLA Anderson School of Management. Available at SSRN: http://ssrn.com/abstract=1347150. 


\title{
BC3 WORKING PAPER SERIES
}

\author{
Basque Centre for Climate Change (BC3), Bilbao, Spain
}

The BC3 Working Paper Series is available on the internet at the following addresses:

$$
\begin{gathered}
\text { http://www.bc3research.org/lits_publications.html } \\
\text { http://ideas.repec.org/s/bcc/wpaper.html }
\end{gathered}
$$

BC3 Working Papers available:

2010-05

2010-06

2010-07

2010-08

2010-09

2010-10

2010-11

2010-12

2010-13

2010-14

2010-15

2010-16

2010-17

Roger Fouquet: The Slow Search for Solutions: Lessons from Historical Energy Transitions by Sector and Service

Ibon Galarraga, Mikel González-Eguino and Anil Markandya: Evaluating the Role of Energy Efficiency Labels: the Case of Dish Washers

Luis M. Abadie, Mikel González-Eguino and José M. Chamorro: Optimal Abandonment of Coal-Fired Stations in the EU

Dirk Rübbelke and Stefan Vögele: Impacts of Climate Change on European Critical Infrastructures: The Case of the Power Sector

Roger Fouquet: The Sustainability of 'Sustainable' Energy Use: Historical Evidence on the Relationship between Economic Growth and Renewable Energy

Karen Pittel and Dirk Rübbelke: Energy Supply and the Sustainability of Endogenous Growth

Ramon Arigoni Ortiz, Alexander Golub, Oleg Lugovoy, Anil Markandya and James Wang: The DICER Model: Methodological Issues and Initial Results.

Elena Ojea, Julia Martin-Ortega and Aline Chiabai: Classifying Ecosystem Services for Economic Valuation: the Case of Forest Water Services

Aline Chiabai, Chiara Travisi, Anil Markandya, Helen Ding, and Paulo Nunes: Economic Assessment of Forest Ecosystem Services Losses: Cost of Policy Inaction

Kaysara Khatun: Competing Ecosystem services: an Assessment of Carbon and Timber in the Tropical forests of Central America

Karen Pittel and Dirk Rübbelke: Local and Global Externalities, Environmental Policies and Growth

Margherita Grasso, Matteo Manera, Aline Chiabai, and Anil Markandya: The Health Effects of Climate Change: A Survey of Recent Quantitative Research

Luis Mari Abadie, Ramon Arigoni Ortiz and Ibon Galarraga: The Determinants of Energy Efficiency Investments in the U.S. 